\title{
Burned Bones Tell Their Own Stories: A Review of Methodological Approaches to Assess Heat-induced Diagenesis
}

\author{
Adriana P. Mamede, ${ }^{\#}$ David Gonçalveso\&\$, M. Paula M. Marques ${ }^{\# \S}$ \\ and Luís A.E. Batista de Carvalho
}

"Unidade de I\&D "Química-Física Molecular", Department of Chemistry, University of Coimbra, 3004-535 Coimbra, Portugal

${ }^{\%}$ Research Centre for Anthropology and Health (CIAS), University of Coimbra, Portugal ${ }^{\&}$ Laboratory of Forensic Anthropology, Centre of Functional Ecology, University of Coimbra, Portugal

${ }^{\$}$ Archaeosciences Laboratory, Directorate General Cultural Heritage (LARC/CIBIO/InBIO), Lisbon, Portugal

${ }^{\S}$ Department of Life Sciences, University of Coimbra, Portugal

*Corresponding Author: 1abc@ci.uc.pt 
Abstract: One of the biggest struggles of biological anthropology is to estimate the biological profile from burned human skeletal remains. Bioanthropological methods are seriously compromised due to bone heat-induced alterations in shape and size. Therefore, it is urgent to improve our ability to estimate sex, age at death, stature and ancestrality, to recognize peri mortem traumas and differentiate them from fractures due to fire, and to determine what was the intensity of burning, namely maximum temperature and heat exposure length. This review focuses on different methodologies to assess heat prompted changes in bone submicrostructure. Some of these are extensively used in burned bones research, namely infrared and Raman spectroscopy and X-ray diffraction, while others such as neutron spectroscopy and diffraction are rarely applied to bone samples although their contribution may be crucial for establishing new bioanthropological methods for a reliable examination of burned victims.

Running Head Title: Spectroscopic probing burned bones

Keywords: Burned Human Bones, Neutron Spectroscopy, Neutron Diffraction, FTIR, Raman, XRD

\section{Contents}

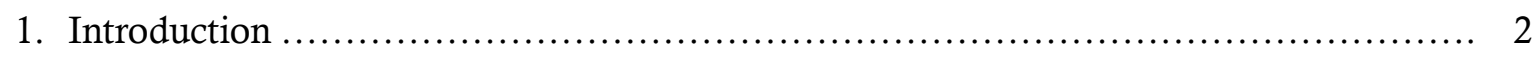

1.1. Burned Bones: What is the Problem? ........................................ 2

1.2. From Archaeological to Forensic Contexts .................................. 2

1.3. Bone Composition .......................................................... 3

1.4. Bone Crystallinity and the Heating Process ..................................... 4

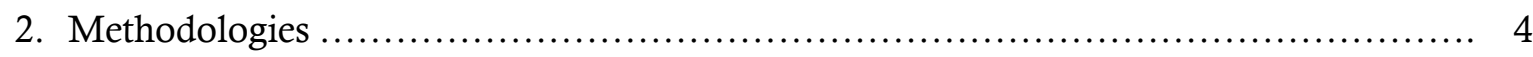

2.1. Vibrational Spectroscopy ................................................ 5

2.1.1. Fourier Transform Infrared Spectroscopy $\ldots \ldots \ldots \ldots \ldots \ldots \ldots \ldots \ldots \ldots \ldots \ldots \ldots \ldots$

2.1.2. Raman Spectroscopy ................................................. 7

2.1.3. Inelastic Neutron Scattering Spectroscopy .................................. 10

2.2. Diffraction Methods ......................................................... 11

2.2.1. X-Ray Powder Diffraction ................................................ 12

2.2.2. Neutron Diffraction ....................................................... 13

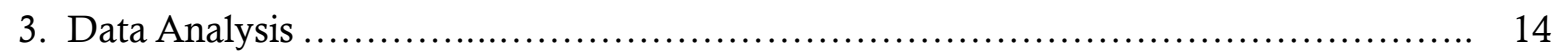

3.1. Vibrational Spectroscopy .............................................. 14

3.1.1. Fourier Transform Infrared Spectroscopy ............................... 15

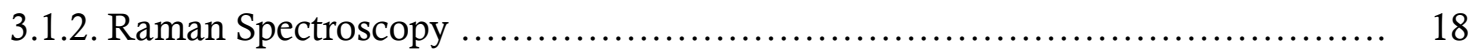

3.1.3. Inelastic Neutron Scattering Spectroscopy ................................... 19

3.2. Diffraction Methods ........................................................ 20

3.2.1. X-Ray Powder Diffraction ............................................. 20

3.2.2. Neutron Diffraction ...................................................... 21

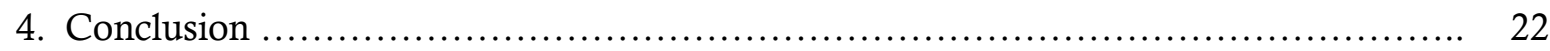

Acknowledgements ........................................................... 23

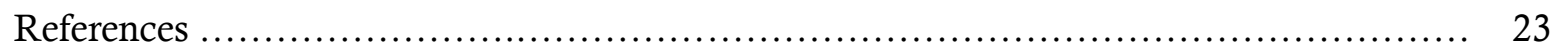




\section{Introduction}

According to the World Health Organization (WHO), more than 300000 deaths occur, per year, caused by fire (1). Hence, it is very common to find burned human skeletal remains in forensic scenarios. The causes of the fires vary from bush fires, car accidents or mass disasters to explosions or bombings, and sometimes they are also associated to suicides or homicides $(2,3)$. As in any other fatal cases, it is a priority of forensic teams to identify the victims and return the remains to their families. In addition, burned skeletal remains are also frequently recovered from archaeological settings (REF). Through this kind of ancient material, bioarchaeologists attempt to assess and describe the demography, the biology and the funerary practices of past populations. Therefore, burned human skeletal remains are a very common object of biological anthropologists.

\subsection{Burned Bones: What is the Problem?}

In scenarios involving fire when only the skeleton remains it is difficult to use the conventional methods during the forensic examination which involve facial recognition, fingerprint and DNA analysis (3-8).

Given the impairments described above, biological profiles, which include the assessment of age at death, stature, sex, and ancestry in both settings are exclusively obtained from bones and teeth and the same occurs with pathologies and traumas $(9,10)$. Regarding burned skeletons, however, many bioanthropological methods are compromised since they are based on bone morphology and metrics (11-15) and heat is known to cause color and size changes, warping and fragmentation $(2,14,16-18)$. Hence, the study of burned human bones allows to better understand heat-induced changes and their impact on bioanthropological methods and is of the utmost relevance for the analysis of both forensic and archaeological contexts.

\subsection{From Archaeological to Forensic Contexts}

In archaeology, the study of burned bones is fundamental to understand funerary behaviors, as well as cooking practices. The examination of archaeological burned remains, from all sort of animals including humans, has been providing important knowledge that has been applied to the research of burned bones associated to forensic settings.

Some studies are mainly based on macroscopic alterations, because it is so important to maintain the remains intact in both areas (archaeology and forensic anthropology). In the highlight of archaeology, the occurrence of warping and thumbnail fractures, color differences and mechanical bone alterations, color changes, shrinkage and weakness, and microscopic bone surface variations (16-24). The potential for archaeological and forensic application of these heat-induced features has been assessed by several authors for example to infer about preservation of corpses 
when exposed to heat, the temperature and duration of the exposure, and the sequence of burial and cooking events $(16,17,25-27)$ but it is still clear that our understanding regarding their occurrence and variability is still partial and more research is needed to validate them as truly reliable evidences able to aid in the determination of the circumstances around death.

For instance, it is now clear that heat-induced macroscopic changes are closely related to submicroscopic alterations triggered by heat $(8,17,28-30)$. Thus analytical methodologies aiming at the elemental composition and the submicroscopic structure started to be applied on burned bones to relate them with the macroscopic ones $(18,29,31-39)$. A review of the state of the art is here provided.

\subsection{Bone Composition}

Bone is a heterogenous material, containing inorganic and organic constituents, apart from water: from the total mass of bone, $60 \%$ is ascribed to the inorganic phase (increasing to $70 \%$ in dry bone), $25 \%$ to the organic components and $9.7 \%$ to water $(35,40-43)$. The organic phase comprises lipids and proteins (mainly type I collagen) and a remaining $2 \%$ representing varied cellular constituents $(40,41,44)$.

The inorganic phase, bioapatite, is a carbonate-substituted hydroxyapatite of approximate formula $\mathrm{Ca}_{10}\left(\mathrm{PO}_{4}\right)_{6-\mathrm{x}}(\mathrm{OH})_{2-\mathrm{y}}\left(\mathrm{CO}_{3}{ }^{2-}\right)_{\mathrm{x}+\mathrm{y}}$. Actually, in vivo, carbonates $\left(\mathrm{CO}_{3}{ }^{2-}\right)$ can substitute for the phosphate groups $\left(\mathrm{PO}_{4}{ }^{3-}\right)$ within hydroxyapatite matrix (type $\mathrm{B}$ substitution) or for the hydroxyl groups $\left(\mathrm{OH}^{-}\right)$(type A substitution, much less common) (45-47), as schematically represented in Figure 1. Once $\mathrm{CO}_{3}{ }^{2-}$ groups have a different charge and geometry than $\mathrm{PO}_{4}{ }^{3-}$ moieties, and are much bigger than the $\mathrm{OH}^{-}$groups, their presence in the crystal lattice generates distortions that lead to a decrease in crystallinity of bioapatite (47-49). Apart from these substitutions, the crystal lattice of bioapatite may contain water and ions such as calcium $\left(\mathrm{Ca}^{2+}\right)$, sodium $\left(\mathrm{Na}^{+}\right)$, magnesium $\left(\mathrm{Mg}^{2+}\right)$, strontium $\left(\mathrm{Sr}^{2+}\right)$, potassium $\left(\mathrm{K}^{+}\right)$, fluorine $\left(\mathrm{F}^{-}\right)$or chlorine $\left(\mathrm{Cl}^{-}\right)(33,35,41,48,50)$. The individual proportion of each bone constituent, as well as its geometric and spatial arrangement, depend on numerous factors, namely: diet, metabolism, pathologies, age at death, post mortem period and type of soil in contact with the remains (51).

Thus, bioapatite has a lower crystallinity than hydroxyapatite due to its high carbonate substitution degree, that is responsible for small sized crystals, with a high structural strain (caused by the distortions and defects within the crystal lattice), a high surface area and an increased solubility in water $(42,52)$. These features confer particular characteristics to the bone matrix, such as resistance and flexibility, and contribute to the mineral homeostasis of the organism $(40,41)$. In addition, lower crystallinity renders bones susceptible to post mortem alterations caused by heat or other environmental factors (e.g. contact with surrounding fluids) (50). 


\subsection{Bone Crystallinity and the Heating Process}

Crystallinity is an indicator of the size and atomic order of a crystal. After death, bioapatite becomes less reactive and its crystallinity increases due to diagenesis.

Diagenesis is by definition the physical and chemical alteration of sediments after its deposition resulting in mineralogic variations. Diagenetic bone alterations include spontaneous recrystallization related to collagen decomposition (following exposure of the crystals of bioapatite to the surroundings) and loss of carbonate and fluorine uptake (53-55). During the burning process, several events similar to diagenesis occur, concomitant with the loss of water and carbonate from the crystal lattice: with increasing temperatures bioapatite becomes analogous to the geological form of hydroxyapatite, with bigger crystals, higher levels of crystallinity and lower porosity (42, 48).

Naturally, the three main components of bone tissue are differently affected by heat $(28,53$, 56). Thompson (14) has defined four different phases for heat-induced changes: (i) dehydration, between 100 and $600{ }^{\circ} \mathrm{C}$; (ii) decomposition, 300-800 ${ }^{\circ} \mathrm{C}$; (iii) inversion, 500-1100 ${ }^{\circ} \mathrm{C}$; (iv) and fusion, above $700{ }^{\circ} \mathrm{C}$. Etok et al. (57) further detailed these four phases: $25-250{ }^{\circ} \mathrm{C}$ includes the loss of poorly bounded water up to $100{ }^{\circ} \mathrm{C}$ and of structural water from proteins and mineral surface-bounded $\mathrm{H}_{2} \mathrm{O}$ up to $250{ }^{\circ} \mathrm{C} ; 300-500{ }^{\circ} \mathrm{C}$ involves the combustion of about $50 \%$ of the organic phase, an increase of crystal size (from ca. 10 to $30 \mathrm{~nm}$ ) and crystal thickness (from ca. 2 to $9 \mathrm{~nm}$ ), and the formation of new mineral phases $\left(\mathrm{NaCaPO}_{4}, \mathrm{NaCl}\right.$ and $\left.\mathrm{KCl}\right)$; above $500{ }^{\circ} \mathrm{C}$, loss of the remaining organic components occurs, along with growth of crystal size to $110 \mathrm{~nm}$ and of crystal thickness to $10 \mathrm{~nm}$, at $800{ }^{\circ} \mathrm{C}$; loss of intercrystallite space is observed, at $900{ }^{\circ} \mathrm{C}$; above $1000{ }^{\circ} \mathrm{C}$, formation of $\beta$-tricalcium phosphate $\left(\mathrm{Ca}_{3}\left(\mathrm{PO}_{4}\right)_{2}\right)$ occurs. So, the first $\mathrm{CO}_{2}$ release takes place between 250 and $500{ }^{\circ} \mathrm{C}$ as the result of organic component combustion, while the second fraction of $\mathrm{CO}_{2}$ is released at $c a .500^{\circ} \mathrm{C}$ consistent with structural carbonate loss $(48,57,58)$. Crystalline structure of bioapatite starts to be affected by heat solely above $500{ }^{\circ} \mathrm{C}$, on account of an organic matrix thermal shielding effect that protects the inorganic moiety leaving only the surface of the crystals exposed to heat after its destruction $(42,57,58)$.

Figure 2 summarizes the heat-induced alterations described above, including color changes (according to Shahack-Gross et al., Shipman et al. and others $(31,59,60))$. Intact bone appears light yellow colored. When exposed to low burning temperatures $\left(<500^{\circ} \mathrm{C}\right)$ bones present dark colors (black, dark brown or dark grey) suggesting charring; as temperature increases, bones progressively assume lighter colors (light grey to white) and, in some cases, tenuous orange, grey, white, yellow and blue lines/spots are observed, indicating calcination. 


\section{Methodologies}

Analysis of bone microstructure may be a difficult and challenging process, even more with all the possible changes (macroscopic, microscopic and submicroscopic) induced by heat. Numerous studies are to be found in the literature based on vibrational spectroscopy techniques, namely Raman (34, 39, 61-63) and Fourier transform infrared (FTIR) (28, 34, 35, 46, 50, 54, 64), X-ray powder diffraction (XRD) $(33,50,57,59,65-67)$, X-ray fluorescence (XRF) $(37,38,68-70)$, thermogravimetric analysis (TGA), differential scanning calorimetry (DSC) (43, 55, 57, 71), scanning electron microscopy (SEM) $(15,43,57,72-75)$, nuclear magnetic resonance (NMR) and magnetic resonance imaging (MRI) $(15,76)$, and computational tomography (CT) (77-79). Obviously, each technique gives different (often complementary) information, their selection being determined by the specific goal to be attained.

The main hope of bioanthropological researchers is to find methods that allow a rapid and reliable estimation of the parameters of the biological profile. The selection of techniques to successfully achieve this goal should follow several criteria: equipment accessibility; maintenance costs; data acquisition time; non-destructive analysis or minimal sample amount needed; virtually no sample preparation; and ease of data analysis. In the light of these criteria, and since forensic and archaeological research facilities are more usually equipped or have easier access to Raman and FTIR than to other apparatus, the present review will focus on vibrational spectroscopic techniques. Another advantage of these equipments is that they provide information on thermally induced changes in both organic and inorganic bone constituents (including crystallinity). In addition, inelastic neutron scattering (INS) spectroscopy will also be discussed, as it allows an unprecedented access to vibrational data unattainable by optical techniques (FTIR and Raman), thus yielding the complete vibrational profile of bone samples by combination with Raman and infrared data. This is essential for an accurate understanding of all modifications undergone within the bone matrix upon heating. In turn, diffraction methods, both conventional X-ray (XRD) and neutron based, deliver crucial information on the crystal parameters, as well as on the chemical composition of the crystal lattice (including the localization of the hydrogen atoms, when using neutron diffraction).

\subsection{Vibrational Spectroscopy}

Atoms within molecules are never motionless, they oscillate around their equilibrium positions (80), changing bond lengths and angles (81). A vibrational spectrum results from transitions between quantized vibrational energy states, each fundamental vibrational mode, $i$, that involves nearly harmonic displacements of the atoms, corresponding to a characteristic frequency, $v_{i}(80,82)$. 


\subsubsection{Fourier Transform Infrared Spectroscopy}

Infrared (IR) spectroscopy is based on the absorption of electromagnetic radiation at frequencies matching the vibrational modes of the molecule, i.e. the incident light with the same energy of a specific vibrational transition is absorbed, originating a spectral band (81-84). However, absorption on the IR range, only occurs if, during the vibration, a change in the molecular electric dipole moment occurs: when electromagnetic radiation, with matching frequency to a vibrational motion, interacts with the fluctuating dipole moment of the molecule and is absorbed $(80,81)$.

The IR spectral region can be divided into far-IR $\left(<200 \mathrm{~cm}^{-1}\right)$, mid-IR $\left(200-4000 \mathrm{~cm}^{-1}\right)$ and near-IR (4000-13000 $\mathrm{cm}^{-1}$ ). The mid-IR region is the more commonly used, since most of the fundamental vibrations occur between 400 and $4000 \mathrm{~cm}^{-1}$. In turn, the far-IR region is relevant for the study of the molecular skeleton through specific vibrations: torsions, crystal lattice modes, H-bond associated stretchings and oscillations involving heavy metals $(81,85)$. The near-IR interval, in turn, comprises overtones (multiples of fundamental vibrational frequencies) and combinations of fundamental modes $(80,81)$.

Interaction of IR radiation with a sample may occur in transmission, reflectance or transflection. In transmission mode the light passes through the sample (81), which is contained within a pellet of an IR transparent support medium, usually $\mathrm{KBr}$ or CsI (for mid-IR). This process comprises grinding in a mortar and applying pressure to form the pellet (that should be homogenous). Apart from the time required for sample preparation, the sample is not recoverable (although the amount needed is very small). Moreover, Thompson et al. (86) and Surovell and Stiner (87) found that this sample handling in FTIR- $\mathrm{KBr}$ analysis, namely grinding, introduces alterations in bone crystallinity. In reflectance mode, light interacts with the surface of the sample. Reflection may be internal, diffuse or specular (all may occur simultaneously, with different contributions), giving rise to internal reflectance spectroscopy (IRS) or attenuated total reflection (ATR), diffuse reflectance spectroscopy (DRS) and specular reflectance spectroscopy, respectively (88). Regarding to the later (DRIFT, diffuse reflectance infrared Fourier transform), it does not require the preparation of a homogeneous pellet, thus eliminating the grinding procedure, but still requires mixing with $\mathrm{KBr}$ which hinders sample recover.

For Fourier transform infrared in ATR mode (FTIR-ATR), the radiation beam enters a crystal with a high reflection index and is internally reflected if the angle of incidence in the sample-crystal interface is greater than the critical angle $(81,88)$, as represented in Figure 3. Interaction between the radiation and the sample occurs on this surface and is dependent on the characteristics of the sample and on the environment. This is a particular suitable technique for rapid and non-destructive analysis of powders since it does not require any type of solvent or support medium, which reduces considerably sample preparation times, and the amount of sample needed is very small $(<1 \mathrm{mg})$. 
Hence, FTIR-ATR appears to be a reliable and quite appropriate technique for bone analysis, as corroborated by Beasley et al. (53). In comparison to FTIR-KBr, it is a better technique to analyze powder samples because it diminishes distortions caused by optical saturation and dispersion, and it is free of chemical sample alterations (water adsorption and ion exchange) possibly produced during $\mathrm{KBr}$ pellet preparation (89).

Despite the fact that all IR techniques give the same chemical information about the sample, differences in resolution of the spectra may occur, as reported by Beasley and coworkers (53) when comparing FTIR-KBr, ATR and DRIFT data, not allowing a direct comparison between spectroscopic indices obtained from these different techniques (see section 3.1.1).

Furthermore, ATR spectra present distortions of the relative peak intensities in comparison to those acquired in transmission mode, since the depth of penetration by the incident radiation is dependent on its wavelength, the higher the wavelength the larger the band intensity, according to the following equation.

$$
d_{p}=\frac{\lambda}{2 \pi n_{1} \sqrt{\sin ^{2} \theta-\left(n_{2} / n_{1}\right)^{2}}}
$$

where $d_{p}$ is the penetration depth, $\lambda$ is the wavelength of the incident radiation, $n_{1}$ and $n_{2}$ are the refraction indices of the crystal and sample, respectively, and $\theta$ represents the incident angle of the radiation $(88,90)$. Moreover, an effect known as anomalous dispersion leads to peaks shifting, because the refraction index of the sample undergoes quick changes nearby an absorption peak (90). Therefore, an ATR correction function should be applied, that removes these effects from the spectra rendering their comparison possible with those obtained in transmission.

The biggest obstacle regarding IR spectroscopic analysis is the interference of $\mathrm{H}_{2} \mathrm{O}$ and $\mathrm{CO}_{2}$, whose signals may override relevant sample spectral information in the $1500-4000 \mathrm{~cm}^{-1}$ range. This problem, however, is easily overcome using a purged FTIR apparatus.

\subsubsection{Raman Spectroscopy}

Raman spectroscopy is a complementary technique to IR spectroscopy, the physical process giving rise to the vibrational bands being different (with distinct selection rules): Raman inelastic light scattering vs. infrared light absorption (80).

Scattering corresponds to deflection of light from the direction of the incident beam. When the electromagnetic radiation interacts with a polyatomic molecule, a periodic perturbation of the electron clouds is induced and an oscillating electric moment is produced. Scattered light is, in reality, emitted radiation by this induced oscillating dipole moment, i.e. electrons can couple with photons and induce scattering (80). This process may be either elastic (Rayleigh scattering) - the scattered light has the same frequency $\left(v_{0}\right)$ as the incident one - or inelastic (Raman scattering), 
involving a change in energy either higher $\left(v_{0}+v_{\text {vib }}\right)$ or lower $\left(v_{0}-v_{\text {vib }}\right)$ relative to the incident radiation (respectively, anti-Stokes Raman scattering or Stokes Raman scattering, as represented in Figure 4). The vibrational energy difference $\left(v_{\mathrm{vib}}\right)$ is the same in both processes, i.e. the energy difference between the incident and scattered light is equal for either Stokes or anti-Stokes process. The later, however, yields less intense bands, since it corresponds to an initial transition from an excited state (Figure 4) which has a lower population than the ground one, thus giving rise to a less intense scattered signal. As a consequence, the Stokes Raman scattering is the one normally detected in Raman experiments. It should be noted that Raman is a very weak process, only a very small fraction of the incident light ( $c a .10^{-6}$ for solids) undergoing inelastic scattering (80).

In sum, the Raman effect is the result of an oscillating induced dipole moment, due to the interaction between the electric field of the incident electromagnetic wave (i.e. the incident monochromatic light beam, nowadays a laser) and the molecular polarizability of a particular molecular vibration. Therefore, vibrational modes will be Raman active if they involve a change in the shape of the electron cloud.

Some vibrational modes will then be visible (active) in Raman but not in IR and vice versa. In order to access the complete vibrational profile of a sample, both Raman and infrared analysis are needed $(82,91)$ (as well as neutron vibrational techniques, if possible, see section 2.1.3).

The main advantages of Raman spectroscopy are: (i) virtually no sample preparation; (ii) small amount of sample needed; (iii) non-destructive (the sample is completely recoverable) and non-invasive; (iv) high specificity; (v) high spatial resolution, mainly when using microspectroscopy setups (coupling Raman scattering and optical microscopy (92)). On the other hand, the major handicap of the technique is its quite low sensitivity and the interference from fluorescence. This determines the choice of the excitation source, the Raman differential scattering cross-section $(\sigma)$ being proportional to the fourth power of the incident laser frequency $\left[\sigma \propto\left(v_{0}-v_{\text {vib }}\right)^{4}\right]$, which favors the use of ultraviolet or visible light sources in order to increase the signal intensity. However, care must be taken in order to avoid fluorescence emission upon light absorption, as the former is a much more intense process than inelastic scattering and can completely overrule the Raman bands of the sample.

Bone tissue analysis using Raman spectroscopy faces serious obstacles, mainly due to the presence of fluorophores within the bone matrix (mainly for intact bone) $(93,94)$. Apart from lipids, collagen is the main organic component of bone and is a strongly fluorescent molecule $(94,95)$. In turn, non-collagenous proteins containing aromatic aminoacids (tyrosine, tryptophan or phenylalanine) are also highly fluorescent (95). With a view to overcome this problem, some measures are in use:

- Purification of the sample - if bone organic matrix is not the focus of the study, one possible approach to eliminate fluorescence is to remove it from the sample. Regarding lipids 
removal, chloroform/methanol and petroleum ether solutions are the most commonly used $(43,96-98)$, although it takes several hours, no negative effects on the mineral lattice having been reported. Concerning to deproteinization, the numerous suggested protocols - using ethylenediamine $(99,100)$, sodium hypochlorite $(100,101)$ or hydrazine $(102)$, among others - were found to affect the inorganic matrix of bone $(100,103,104)$, which requires the development of improved methods.

- Bleaching - either photobleaching - photochemical destruction of the fluorophore(s) by prolonged exposure of the sample to the laser beam (80) - or chemical bleaching - removal or significant damage of the fluorophore by treatment with organic solvents. Although chemical bleaching effectively reduces fluorescence, it may also damage the sample (93, 105). Photobleaching, in turn, is still a poorly understood phenomenon, thought to involve photon induced chemical damage and chemical changes within the fluorophore that, lead to quenching (105). Nevertheless, photobleaching can also cause sample damage: Golcuk et al. (93) found that prolonged photobleaching of dry bone prompted variations in the area of mineral to matrix bands, and suggested that this might be due to photolysis of collagen cross-links or to dehydration upon continuous laser incidence (leading to heating).

- Choice of excitation wavelength - since fluorescence emission strongly depends on the excitation wavelength, a careful selection of the excitation source may avoid (or at least decrease) fluorescence interference (80). Yet, one should keep in mind that, as discussed above, high wavelength lasers give rise to less intense Raman signals. In bone analysis, laser beams are typically within the range of $514 \mathrm{~nm}$ to $1064 \mathrm{~nm}$ (34), the latter being used in Fourier Transform Raman instruments (FT-Raman).

- Surface Enhanced Raman Spectroscopy (SERS) - since the problem of fluorescence is its high intensity compared to Raman scattering, by increasing the Raman intensity this may be partially overcome. The SERS phenomenon leads to an enhancement of the Raman signal up to $10^{6}$ upon adsorbance of the sample molecule to rough surfaces or colloids, usually of gold, silver or copper $(106,107)$. The basis of this effect lays on the creation of a strong electromagnetic field caused by the excitation of the localized surface plasmon resonance of nanoscale roughness of the metal $(107,108)$. This field leads to an increase of the induced dipole and therefore of the Raman scattering.

- Coherent Anti-Stokes Raman Scattering (CARS) - the CARS effect is a four photon process based on a non-linear optical technique that yields Raman data in the anti-Stokes region with an improved signal strength. Two colinear lasers with different frequencies are used: the pump laser, with a stationary frequency, $\left(\omega_{\text {pump }}=\omega_{\text {probe }}\right)$ and the Stokes scanning laser $\left(\omega_{\text {Stokes }}\right)$. These two radiations interact with the sample generating photons inelastically scattered within the anti-Stokes frequency region according to equation 2 : 


$$
\omega_{\text {anti-Stokes }}=\omega_{\text {pump }}+\left(\omega_{\text {probe }}-\omega_{\text {Stokes }}\right)=\omega_{\text {pump }}-\omega_{\text {Stokes }}+\omega_{\text {probe }}=2 \omega_{\text {pump }}-\omega_{\text {Stokes }}
$$

In the case of collinear geometry of excitation, the light with frequency $\omega_{\text {anti-stokes }}$ is emitted in the forward direction, colinear to the laser beams, as the result of inelastic scattering of the sample $(80,109,110)$. With the use of these two colinear lasers, most molecules will be prompted into a virtual excited state and when relaxing to the ground electronic state the emitted radiation will be more energetic than the incident beam, resulting in anti-Stokes Raman scattering, as represented in Figure 5.

If the frequency difference $\omega_{\text {pump }}-\omega_{\text {Stokes }}$ matches a vibrational frequency transition $\left(\omega_{\text {vib }}\right)$, the signal obtained is approximately four orders of magnitude stronger than conventional Raman scattering. Besides the enhanced signal, the anti-Stokes region is blue shifted and thus is spectrally free of fluorescence background $(80,110,111)$. This feature renders CARS a very attractive technique for medical and biochemical purposes and might be a possible approach to eliminate fluorescence during Raman analysis of bones and teeth in forensic and archaeological sciences.

\subsubsection{Inelastic Neutron Scattering Spectroscopy}

Inelastic neutron scattering (INS), as FTIR and Raman optical techniques, is a vibrational spectroscopy method very useful for attaining a complete vibrational profile of a system (by coupling all three techniques). In this case, a neutron beam is applied to the sample and interacts with the nucleus, undergoing inelastic scattering $(112,113)$ and generating an INS signal that results from the energy difference between the scattered neutron and the neutron beam (that matches the energy of the vibrational mode), similarly to the optical Raman scattering process. Obviously, optical rules do not apply when using neutrons as an excitation source. In other words, as the mass of the neutron is 2000 times greater than that of the electron, the inelastic scattering event involves not only energy transfer $\left(\mathrm{E}, \mathrm{cm}^{-1}\right)$ but also momentum transfer $\left(\mathrm{Q}, \AA^{-1}\right)$. The momentum, $\mathrm{Q}=k_{\mathrm{f}}-k_{i}$, depends on the wavevector, $k$, defined as:

$$
k=\frac{2 \pi}{\lambda}
$$

where $\lambda$ is the wavelength of the incident neutron (114). These wavelengths are within the scale of internuclear distances, contrary to optical spectroscopy were the photon wavelength is larger than the charge distribution alterations associated to excitation $(98,115)$. So, $k$ assumes a very small value for any scattering angle and $\mathrm{Q}$ is also very small. Thus in both Raman and IR only the 
vibrational transitions at zero wavevector are visible (114) while in INS every wavevector is observable and, consequently, every vibrational mode can be detected.

The experimentally measured scattered function is defined as:

$$
\mathrm{S}(\mathrm{Q}, \omega)=\sigma \mathrm{Q}^{2} \mathrm{U}^{2} \omega^{-Q^{2} U_{T}^{2}}
$$

where $\sigma$ is the scattering cross section, $Q$ is the momentum transfer in $\AA^{-1}$, and $U$ is the amplitude of the vibration in $\AA$ ( $\mathrm{U}^{2}=h / 4 \pi \mu \omega, h$ being the constant of Plank, $\mu$ the mass of the oscillator, and $\omega$ is the oscillator frequency) $(98,113)$.

Since the scattering function is dependent on the cross section of the nucleus, the biggest the cross section the more intense the INS signal. This is why the technique is particularly informative for groups containing a high amount of hydrogen atoms, as the cross section of $\mathrm{H}$ atom is $c a .20$ times greater than that of all other elements $(96,98)$ - INS spectra are dominated by data on hydrogen content of the sample. Also, hydrogen scatters neutrons isotropically because it is much smaller than the wavelength of the radiation (112).

In neutron diffraction methods, the neutron beam is produced in a nuclear reactor or in a spallation source (that involves previous particle acceleration in a synchrotron) and must be "monochromatic" (all the neutrons in the beam have the same velocity) (116). The greatest advantages of INS spectroscopy are: (i) absence of selection rules; (ii) peak intensities (represented by the scattering function) are directly proportional to the number of scattering atoms and vibrational amplitudes (96, 98, 113); (iii) the neutron radiation is highly penetrating and the scattering is strongly sensitive to isotopic substitution. In turn, the biggest drawbacks of the technique are: (i) the fact that it is extremely costly and can only be carried out at dedicated facilities, since it relies on the generation of an efficient neutron beam either in spallation sources or in nuclear reactors; (ii) significant amount of samples is needed $(1-6 \mathrm{~g})(113,117,118)$. Hence, INS analysis is only performed when other techniques are inadequate or do not provide all the information needed about the sample.

INS has a critical role in bone analysis, namely to confirm the presence of hydroxyl groups in the crystal lattice of hydroxyapatite $(56,96-98)$. Still, as bone matrix also comprises lipids and proteins (with many hydrogen atoms) it is impossible to obtain reliable INS information on the inorganic matrix lattice of the bone without prior removal of these organic components (that would overrule the signals of bioapatite) (56). Although INS is an extremely suitable technique for the study of structural changes in bone, it has been seldom used, the works by Taylor et al. (96) and Marques et al. (56) being some of the few reported studies in animal and human bone based on combined INS, FTIR and Raman measurements. The latter (56), was the first investigation of heat-induced alterations in human bones by inelastic neutron scattering. 


\subsection{Diffraction Methods}

Diffraction is a phenomenon that occurs whenever a coherent wave is targeted onto a set of objects equally spaced, visible when the wavelength of the incident wave is of the same order of magnitude than the distance between the objects (119). Diffraction occurs due to the interference between distinct reflected waves dependent on differences in the path travelled by the radiation, which results in variations on the amplitude - hence, path and phase differences are directly proportional.

Electromagnetic waves or particles may be used in diffraction methods, such as X-rays, neutrons and electrons (116).

In crystalline materials, atoms are equally spaced and display defined patterns, yielding a unit cell that is periodically repeated in three dimensions (of the same order of some Angstroms). This renders them ideal candidates for analysis by diffraction methods $(116,119)$. As the diffracted beam comprises many scattered rays and differences in the path travelled by these are related to the space between the different atoms, diffractograms reflect the crystal structure being characteristic and unique of each crystalline compound (a fingerprint), thus allowing its unmistakable identification.

\subsubsection{X-Ray Powder Diffraction}

In conventional setups, X-rays are produced in an X-ray tube consisting of a source of electrons and two metal electrodes. The X-ray radiation is obtained at the point of impact between electrons and the anode. The wavelength of the radiation will vary depending on the metal used as anode and on the voltage applied to the tube used. The latter has to be raised above a critical value, so that the intensity of the radiation is the maximum at that specific wavelength. However, the obtained beam does not comprise only one wavelength and it is necessary to use a filter for decreasing the intensity of the other produced wavelengths. This filter is made of a metal with an atomic number one less than that of the anode, e.g. in bones research the anode usually used is copper $(Z=29)(33,37,65-68)$, the filter consists of nickel $(Z=28)(119)$.

Apart from these traditional X-ray source, there are also synchrotron-based equipments, with high performance due to the brilliance of the produced beam.

For a crystalline sample to diffract X-rays the Bragg law must be obeyed,

$$
\lambda=2 \mathrm{~d} \sin \theta
$$

for a crystal lattice with its planes equally spaced at a distance $d$, a beam of perfectly monochromatic X-rays, of wavelength $\lambda$, parallel to the crystal planes, incident on the crystal at an 
angle $\theta$ (Bragg angle). Only the diffracted rays that are in phase with each other will constructively contribute to the diffracted beam (119).

In order to carry out structure analysis of crystals by X-ray diffraction, Bragg law is applied using X-rays of known wavelength $(\lambda)$, measuring $\theta$ and thus determining the value of $d$, the space between different planes in the crystal. The orientation of these lattice planes, in turn, is described by indices that are the reciprocals of the fractional intercepts of the plane with the crystallographic axes, defined as $(h k l)$, so if the axial lengths of the plane are $\mathrm{a}, \mathrm{b}$ and $\mathrm{c}$, the plane makes fractional intercepts at $\mathrm{a} / h, \mathrm{~b} / k$ and $\mathrm{c} / l$, and each plane will diffract X-rays with a different angle $(\theta)(119)$. As inferred by Bragg law, the glancing angles $\theta$ at each plane diffracting X-rays, depend on the interplanar spacing $d$, which is determined by the dimensions of the crystal lattice. This means that the atom arrangement in the lattice does not influence the positions of the X-ray reflections and consequently two chemically different compounds with similar crystal dimensions will have analogous X-ray diffractograms (120). This feature is very useful in case of bioapatite and hydroxyapatite that become similar at some point upon thermal exposure.

For powder methods, as opposed to crystal analysis, the sample is reduced to a fine powder in order to have small crystals randomly oriented. Ideally, the highest number of different crystal orientations should be present so that, by chance, there are a few with a correct orientation for satisfying Bragg law. In other words, considering a certain $h k l$ reflection, a few crystals will have their $(h k l)$ planes oriented with the correct Bragg angle for diffraction (119).

The biggest limitation of the XRPD method is the fact that amorphous materials are unable to diffract X-rays. In turn, it is a non-destructive technique, sample preparation is straightforward, short acquisition times are needed and data analysis is usually simple.

As discussed in sections 1.3 and 1.4, due to carbonate substitutions in the lattice of bioapatite its crystallinity is quite low when compared to hydroxyapatite. Nevertheless, after death (at environment temperature) or when the skeletal remains are exposed to heat (high temperatures), crystallinity of bioapatite becomes higher and the chemical composition of bone varies to resemble hydroxyapatite. These alterations have been corroborated through XRPD analysis by several authors: Rogers and Daniels heated cortical bone from femur epiphysis in the range $200-1200{ }^{\circ} \mathrm{C}$ (for $2 \mathrm{~h}$, with a $200{ }^{\circ} \mathrm{C}$ increment), and found a change in the bone crystallites regarding structure and size above $800{ }^{\circ} \mathrm{C}(65)$. Later, Piga et al. verified that heat $\left(200-1000^{\circ} \mathrm{C}\right)$ induced alterations in human femur and teeth that were clearly observable in XRD diffractograms for different burning periods - an increase of the average crystal size was observed with temperature, especially above $800{ }^{\circ} \mathrm{C}$, and new inorganic phases such as $\mathrm{CaO}$ appeared, thus showing the potential of this technique for estimation of burning time and temperature (66). More recently, these conclusions were corroborated by the same authors, when they compared fossil and burned modern bones through a multi-technique methodology (including XRPD) (36). 


\subsubsection{Neutron Diffraction}

Neutrons are neutral particles present in the nucleus of the atom that easily penetrate most materials and can be scattered by nuclei and magnetic fields, as discussed above (section 2.1.3). Similarly to X-ray diffraction, the process of neutron diffraction must follow Bragg law. In neutron powder diffraction, the detector rotates around the sample and the signal is detected as a function of the scattering angle $2 \theta$.

The major difference between these two methods is that while X-rays interact with the electron cloud, providing information on the crystal lattice based on electron density (that suffers interferences from chemical binding), neutron radiation interferes with the nuclei within the sample, with both energy and momentum transfer. Hence, it depends on the atomic number $(\mathrm{Z})$ and the nuclear energy levels of the sample. Information about the nuclear density can thus be obtained, including nuclear positions, and it is possible to distinguish elements with a diffraction amplitude far from the average $(116,119)$.

The biggest disadvantages of neutron diffraction are basically those previously mentioned for INS: an expensive technique that can be applied only at dedicated facilities, and a reasonably high amount of sample needed. The advantages, in turn, when comparing with X-ray diffraction, are the high penetrating ability of the neutron beam, the dependency of the signal intensity as a function of the atomic number thus yielding information on both chemical composition and structure (116, 119).

The first studies applying neutron diffraction to burned human bones are ongoing (at the University of Coimbra, Portugal), to complement X-ray diffraction information on the same samples, with a view to elucidate heat-induced diagenesis at the molecular level: namely the appearance of new inorganic phases within the bone, the detection of $\beta$-tricalcium phosphate $(\beta$ TCP) that is still unexplained (37), and changes in crystal structure parameters $(121,122)$.

\section{Data Analysis}

\subsection{Vibrational Spectroscopy}

Table 1 comprises the main infrared, Raman and INS vibrational modes detected for human bone samples.

Complementarity between infrared, Raman and INS spectroscopy techniques is evident from analysis of the data, evidencing the particular spectral ranges accessed by INS - mainly the low frequency interval, containing the librational, translational and lattice modes characteristic of the biological matrix. 
The need for quantifying heat induced changes observed in the vibrational spectra of bone samples requires the establishment of ratios and indices reflecting specific information such as: (i) the relative amount of bone constituents - phosphate, type A and B carbonates (which correspond to the carbonates in $\mathrm{A}$ and $\mathrm{B}$ sites, respectively), $\mathrm{OH}^{-}$groups and organic matrix constituents (lipids and protein); (ii) crystallinity index (CI); (iii) formation of new inorganic phases, whenever these are related to heat-induced alterations.

It should be highlighted that most of the studies designed for burned bones are based on animal bone samples, very scarce work having been developed for human samples. As differences related to the anatomy, way of locomotion, metabolism, texture and quality (structure and composition) of the bones between humans and animals (usually pig, sheep, cow, dugong, rat or rabbit) may represent important factors of variation. Hence, they must be considered when comparing the spectroscopic results obtained from animal samples with those gathered from human samples, whether these are archaeological or recent.

\subsubsection{Fourier Transform Infrared Spectroscopy}

One of the most important indices applied to the analysis of burned bones by infrared spectroscopy is the crystallinity index (CI), more than one method having been reported for its measurement (123-125). The most widely used CI ratio is the one proposed by Weiner and BarYosef (126), based on the work by Termine and Posner (127), that reflects the combination between the relative sizes of the crystals and the atomic order within the lattice. Consequently, larger and/or more ordered crystals will have a higher CI value, which is obtained through the equation 6 (as represented in Figure 6):

$$
\mathrm{CI}=\frac{\mathrm{A}+\mathrm{C}}{\mathrm{B}}=\frac{\mathrm{Abs}_{565}+\mathrm{Abs}_{603}}{\mathrm{Abs}_{595}}
$$

where $\mathrm{Abs}_{565}$ and $\mathrm{Abs}_{603}$ are the maxima of the bands assigned to the phosphate antisymmetric stretching mode $\left(v_{4}\left(\mathrm{PO}_{4}{ }^{3}\right)\right)$, that is triply degenerate and appears split into two well defined features (due to the anisotropic electric field of crystalline apatite), and $\mathrm{Abs}_{595}$ refers to the minima between these signals. The crystallinity index represents the magnitude of this splitting (128). Accordingly, its value is expected to increase with temperature, rendering it a very promising parameter for estimating burning temperatures. Nevertheless, many researchers have revealed that the CI value grows up to $700-800{ }^{\circ} \mathrm{C}$ and slightly decreases at higher temperatures $(35,48,58,125,129)$ as a consequence of sintering and melting of the crystals (130). Furthermore, Piga and coworkers found that the $v_{4}\left(\mathrm{PO}_{4}{ }^{3-}\right)$ bands can be affected by other features from similar phosphate groups (37).

A different ratio regarding crystallinity and maturity estimation is based on the ratio between the areas of the peaks at 1020 and $1030 \mathrm{~cm}^{-1}(125,131)$, assigned to $v_{1}, v_{3}\left(\mathrm{PO}_{4}{ }^{3-}\right)$ domain. Thus, 
this ratio is a good estimate of the proportion of non-stoichiometric apatite (containing $\mathrm{HPO}_{4}{ }^{2-}$ and/or $\left.\mathrm{CO}_{3}{ }^{2-}\right)$ to stoichiometric apatite $\left(\mathrm{Ca}_{10}\left(\mathrm{PO}_{4}\right)_{6}(\mathrm{OH})_{2}\right)$, and is expected to decrease for increasing temperatures. However, the $\mathrm{CI}$ and $\mathrm{A}(1020) / \mathrm{A}(1030)$ ratio yield insufficient information on post mortem and/or heat-induced changes in bone $(54,125,129)$, other quantitative relationships having been developed with a view to better assess these changes.

Note that any parameters involving bands in the range $1400-1550 \mathrm{~cm}^{-1}$ should be used with care since this spectral region may display quite intense bands due to lipids, proteins and carbonates (Table 1).

Carbonate to phosphate ratio $(\mathrm{C} / \mathrm{P})$, is usually calculated by $\left(\operatorname{Abs}\left(1415 \mathrm{~cm}^{-1}\right) / \operatorname{Abs}\left(1035 \mathrm{~cm}^{-1}\right)(35,58,132)\right.$, giving information about the carbonate content. Despite the signal at $1035 \mathrm{~cm}^{-1}$, assigned to $v_{3}\left(\mathrm{PO}_{4}{ }^{3}\right)$, being a good reference for the total content of phosphate, since it is not affected by any splitting nor overlapped by any other relevant signal, this ratio is calculated using the intensity of the $1415 \mathrm{~cm}^{-1}$ band, which is assigned to $\mathrm{B}$ carbonates $\left(v_{3}\left(\mathrm{CO}_{3}{ }^{2-}\right)_{\mathrm{B}}\right)$ only (Table 1). Therefore, this index refers solely to the content on type $\mathrm{B}$ carbonates. Although, Pucéat et al. (129) have proposed a different relationship for C/P $\left.\operatorname{Abs}\left(1460 \mathrm{~cm}^{-1}\right)+\operatorname{Abs}\left(1425 \mathrm{~cm}^{-1}\right)\right) /\left(\operatorname{Abs}\left(603 \mathrm{~cm}^{-1}\right)+\operatorname{Abs}\left(565 \mathrm{~cm}^{-1}\right)\right)$ - the former is preferred since the peak at $1035 \mathrm{~cm}^{-1}$ is independent of the phosphate band splitting. Moreover, at $1460 \mathrm{~cm}^{-1}$ there is overlapping between the bands assigned to $\delta\left(\mathrm{CH}_{2}\right)_{\text {lipids }}$ and $v_{3}\left(\mathrm{CO}_{3}\right)_{\mathrm{B}}$.

Another index is the type B carbonate to phosphate ratio (BPI), calculated by $\operatorname{Abs}\left(1415 \mathrm{~cm}^{-1}\right) / \operatorname{Abs}\left(603 \mathrm{~cm}^{-1}\right)$ and representing the amount of type $\mathrm{B}$ carbonates $(48,133)$. Both the $\mathrm{C} / \mathrm{P}$ and $\mathrm{BPI}$ ratios are inversely proportional to $\mathrm{CI}$. The higher these values the higher is the amount of type B carbonates. Regarding CI, lower values correspond to smaller bioapatite crystals with higher lattice strain. An increase in temperature is therefore expected to induce a decrease in the $\mathrm{C} / \mathrm{P}$ and $\mathrm{BPI}$ ratios, due to carbonate loss (as $\mathrm{CO}_{2}$ ). Thompson and collaborators (30) have verified that $C / P$ undergoes significant changes at burning temperatures of 500 and $700{ }^{\circ} \mathrm{C}$, the same behavior being expected for BPI. However, this study was carried out with bovina bone samples that may not have the same behavior as human samples. Snoeck and coworkers (48) determined the BPI values for experimentally heated animal bone and for archaeological cremated human bone samples, concluding that charred bone displays higher BPI values than calcined bone (subjected to higher temperatures). Besides, the comparison between these two types of samples revealed that experimentally heated bone had a lower type B carbonate content and a higher type A carbonate concentration, which is still not totally understood. Once again, the modern samples experimentally burned under controlled conditions of animal origin and not human, which is possibly, the source of the difference observed, in addition to post burial diagenesis undergone by archaeological samples.

As temperature increases above $700{ }^{\circ} \mathrm{C}$, however, the data must be analyzed with care since the intensity of the $1415 \mathrm{~cm}^{-1}$ band (carbonate $\mathrm{B}$ ) diminishes considerably. Consequently, both $\mathrm{C} / \mathrm{P}$ 
and BPI ratios fail to represent heat-induced changes caused by high burning temperatures (similarly to CI).

The API index represents the amount of type A carbonate within the bone matrix, and is calculated through $\operatorname{Abs}\left(1540 \mathrm{~cm}^{-1}\right) / \operatorname{Abs}\left(603 \mathrm{~cm}^{-1}\right)(48,133)$. This relationship would be expected to decrease with an increasing temperature, as a consequence of carbonate loss but, type A carbonate content appears to increase concomitantly with the decrease of type B carbonates up to $800{ }^{\circ} \mathrm{C}$ (calcined bone) (as reported by Snoeck et al. (48)). Additionally, other ratios will be affected, namely the $\mathrm{C} / \mathrm{C}$ ratio, discussed below. Once again, care must be taken regarding API values, on account of overlapping peaks near $1540 \mathrm{~cm}^{-1}$ (to amide II band) arising from carbonized organic matter and type A carbonate. Naturally, once the organic matter is totally destroyed this stops being a problem.

Another ratio was proposed by Thompson et al. (58) regarding carbonate to phosphate content, $\mathrm{CO}_{3} / \mathrm{P}$ calculated through $\left(\operatorname{Abs}\left(900 \mathrm{~cm}^{-1}\right) / \operatorname{Abs}\left(1035 \mathrm{~cm}^{-1}\right)\right)$ and useful for samples subjected to low burning temperatures $\left(<400{ }^{\circ} \mathrm{C}\right)$. The $v_{2}\left(\mathrm{CO}_{3}{ }^{2-}\right)$ band is ascribed to the peak at $c a$. $878 \mathrm{~cm}^{-1}$. Thompson and coworkers do not justify the shift from $900 \mathrm{~cm}^{-1}$, but it may be associated to a different environment of the type A carbonates (46). This peak at $878 \mathrm{~cm}^{-1}$ is easily affected by the $v_{1}\left(\mathrm{PO}_{4}\right)$ band broadening which can lead to superimposition of both bands.

The $\mathrm{C} / \mathrm{C}$ ratio is described as $\left(\operatorname{Abs}\left(1450 \mathrm{~cm}^{-1}\right) / \operatorname{Abs}\left(1415 \mathrm{~cm}^{-1}\right)\right)$. According to Snoeck et al. (48) in calcined bone (exposed to temperatures above $800{ }^{\circ} \mathrm{C}$ ) no organic material is left, so the peak at $1450 \mathrm{~cm}^{-1}$ may be ascribed to a combination of type $\mathrm{A}$ and $\mathrm{B}$ carbonates which renders $\mathrm{C} / \mathrm{C}$ a reliable representation of the carbonate $(A+B)$ to carbonate $B$ relationship. Those authors concluded that the $\mathrm{C} / \mathrm{C}$ ratio increases from 600 to $900{ }^{\circ} \mathrm{C}$, reflecting an increase of type $\mathrm{A}$ carbonate relative to type B, probably due to a transfer from B to A sites, as observed by Holcomb and Young (134). Alternatively, it may represent a decrease of type B carbonates, since both organic material and carbonate content are lost at high temperatures $\left(900^{\circ} \mathrm{C}\right.$ and above). It should be highlighted that this parameter has been mistakenly ascribed to the carbonyl to carbonate ratio (86), which originated from an incorrect assignment of the vibrational feature centered at $1450 \mathrm{~cm}^{-1}$ that is due to both carbonate $(\mathrm{A}+\mathrm{B})$ and $\mathrm{CH}_{2}$ deformations from the lipid components of bone. In fact, the carbonyl stretching (including that from amide bonds within a protein - amide I) occurs at a much higher wavenumber, $c a .1650 \mathrm{~cm}^{-1}$.

The $\mathrm{OH} / \mathrm{P}$ ratio, proposed by Snoeck et al. (48), corresponds to $\left(\mathrm{Abs}\left(630 \mathrm{~cm}^{-1}\right) / \mathrm{Abs}\left(603 \mathrm{~cm}^{-}\right.\right.$ $\left.{ }^{1}\right)$ ) and represents the amount of $\mathrm{OH}^{-}$groups within the bone matrix. During the heating process type A carbonates are lost and likely replaced by hydroxyl groups, which results in two absorbance bands at 630 and $3572 \mathrm{~cm}^{-1}$. These peaks, appearing at temperatures around $700{ }^{\circ} \mathrm{C}$, are therefore very useful for the analysis of bone samples subject to high temperatures $(35,56,58)$. Furthermore, INS recent measurements allowed to simultaneously detect $\mathrm{OH}^{-}$libration of hydroxiapatite and 
stretching bands (at 639 and $3572 \mathrm{~cm}^{-1}$, respectively) (56), which may be a good way to track $\mathrm{OH}$ content variations, namely by calculating $\operatorname{Abs}\left(3572 \mathrm{~cm}^{-1}\right) / \operatorname{Abs}\left(603 \quad \mathrm{~cm}^{-1}\right)$ or $\operatorname{Abs}\left(3572 \mathrm{~cm}^{-1}\right) / \operatorname{Abs}\left(1035 \mathrm{~cm}^{-1}\right)$.

In addition, Snoeck et al. showed that the presence of cyanamide $\left(\mathrm{CN}_{2}^{2-}\right)$ in bone is easily identified through two bands at 700 and $2010 \mathrm{~cm}^{-1}$ (48). According to Habelitz et al. (135), incorporation of cyanamide into the apatite structure occurs as a consequence of heating above $900{ }^{\circ} \mathrm{C}$ in the presence of ammonia. The $\mathrm{CN}_{2}{ }^{2-}$ moieties will occupy either hydroxyls or type A carbonates sites in the HAp lattice. Zazzo et al. (136), in turn, proposed a qualitative ratio to estimate the relative content of cyanamide, $\mathrm{CN} / \mathrm{P}=\mathrm{Abs}\left(2010 \mathrm{~cm}^{-1}\right) / \mathrm{Abs}\left(1035 \mathrm{~cm}^{-1}\right)$, which is useful for determining the combustion conditions of a particular sample (although it cannot identify the origin of the ammonia during the burning process). Snoeck et al. (48) found cyanamide in bone samples heated under controlled conditions (without fuels) and in fleshed and non-fleshed bones burned in outdoor pyres - but could not unveil a plausible explanation to the appearance of this compound.

The $\mathrm{CO} / \mathrm{P}, \mathrm{CO} / \mathrm{CO}_{3}$, phosphate high temperature $(\mathrm{PHT})$ and the $\mathrm{FWHM}$ were all proposed by Thompson et al. (58) and they are calculated by: $C O / P=A b s\left(1650 \mathrm{~cm}^{-1}\right) / \operatorname{Abs}\left(1035 \mathrm{~cm}^{-1}\right)$, $\mathrm{CO} / \mathrm{CO}_{3}=\operatorname{Abs}\left(1650 \mathrm{~cm}^{-1}\right) / \operatorname{Abs}\left(1415 \mathrm{~cm}^{-1}\right), \operatorname{PHT}=\operatorname{Abs}\left(625 \mathrm{~cm}^{-1} / 610 \mathrm{~cm}^{-1}\right), \mathrm{FWHM}, 1035 \mathrm{~cm}^{-1}$. These indices showed to have different behaviors depending on temperature, what can be helpful estimating burning temperatures: e.g. $\mathrm{CO} / \mathrm{P}$ and $\mathrm{CO} / \mathrm{CO}_{3}$ can only be obtained at low burning temperatures (before the total combustion of the organic matrix), and PHT refers to samples heated at temperatures above $700{ }^{\circ} \mathrm{C}$.

Combining the information given by all ratios and indices, it is expected that BPI, $\mathrm{A}(1020) / \mathrm{A}(1030), \mathrm{C} / \mathrm{P}, \mathrm{CO} / \mathrm{CO}_{3}$ and $\mathrm{CO} / \mathrm{P}$ ratios and $\mathrm{FWHM}$ decrease, while API, OH/P, PHT and $\mathrm{CI}$ increase with temperature, concomitantly with the possible appearance of cyanamide. This is a consequence of loss of water, organic matrix combustion, reorganization of the crystal structure and the formation of new inorganic phases during the heating process.

\subsubsection{Raman Spectroscopy}

The existing relationships from Raman data on bone (Table 2) were determined mostly for use in medical settings: mineral to matrix ratio (to assess bone quality), carbonate to phosphate index, mineral maturity to crystallinity and parameters regarding collagen quality (137-139). These ratios are valid for diagenetically altered bones, including burned samples $(34,56)$.

Mineral to matrix ratio, that reflects the amount of mineralization of the bone organic matrix, is calculated by the ratios of the integrated areas of the peaks corresponding to: $v_{2}\left(\mathrm{PO}_{4}{ }^{3-}\right)$, at $410-460 \mathrm{~cm}^{-1}$, and amide III, at $1215-1300 \mathrm{~cm}^{-1}(137,138), v_{4}\left(\mathrm{PO}_{4}{ }^{3-}\right)$, at $589 \mathrm{~cm}^{-1}$, and amide III, at $1215-1300 \mathrm{~cm}^{-1}(140)$ or $v_{1}\left(\mathrm{PO}_{4}{ }^{3-}\right)$, at $903-991 \mathrm{~cm}^{-1}$ and the amide I, at $1616-1720 \mathrm{~cm}^{-1}(141)$. The 
formers being more reliable, as they are less affected by tissue orientation $(139,140)$. With an increase in temperature, it is expected that the mineral to matrix ratio increase due to loss of organic components of bone (until it is impossible to calculate because of amide I and III bands disappearance).

Mineral maturity/crystallinity reflects the chemical composition of bioapatite crystallites, being related to their size and distribution, and is estimated by the inverse of full width at half maximum (FWHM) of the $v_{1}\left(\mathrm{PO}_{4}^{3}\right)$ band, at $960 \mathrm{~cm}^{-1}(137,141)$. As the temperature increases, bioapatite becomes more similar to hydroxyapatite and the $v_{1}\left(\mathrm{PO}_{4}{ }^{3-}\right)$ band gets sharper due to carbonate loss (142). It is thus, expected that the mineral maturity/crystallinity increases for higher temperatures.

Carbonate to phosphate ratio, similarly to $\mathrm{C} / \mathrm{P}$ obtained from FTIR data, provides information on the chemical composition and structure of the crystals (e.g. type B carbonate content). It is calculated by the ratio of the integrated areas of the $v_{1}\left(\mathrm{CO}_{3}{ }^{2-}\right)$ band, at $1070 \mathrm{~cm}^{-1}$, to the band $v_{1}\left(\mathrm{PO}_{4}^{3-}\right)$, at $960 \mathrm{~cm}^{-1}(143)$. An increase in temperature is expected to lead to a decrease of the carbonate/phosphate ratio (due to carbonate loss). This ratio must be use carefully, however, due to the partial overlap with the $v_{3}\left(\mathrm{PO}_{4}{ }^{3-}\right)$ feature. An alternative ratio is the integrated areas of the $v_{1}\left(\mathrm{CO}_{3}^{2-}\right)$ band to the peak $v_{2}\left(\mathrm{PO}_{4}^{3-}\right)$, at $428 \mathrm{~cm}^{-1}$ eliminating the contribution of tissue orientation (139). However, the partial superimposition between the $v_{1}\left(\mathrm{CO}_{3}{ }^{2-}\right)$ and $v_{3}\left(\mathrm{PO}_{4}{ }^{3-}\right)$ bands still occurs.

The indices developed to assess collagen quality within the bone are the relative content of pyridinoline, proteoglycan, glycosaminoglycan and lipids, as well as a measure of the quality of collagen cross-links (137). Once they provide information about bone metabolism and remodeling, they are not very useful in diagenetically altered (137). To assess collagen preservation in skeletons, in turn, the peak height ratio $v_{1}\left(\mathrm{PO}_{4}{ }^{3-}\right) / v(\mathrm{CO})_{\text {Amide I }}(39)$, is expected to increase with an increase in temperature (until it is impossible to calculate due to organic matrix total combustion).

Table 2 comprises the parameters associated to heat induced alterations in bone, based on FTIR and Raman data. Although FTIR and Raman parameters are not directly comparable, the information from both techniques is expected to agree.

\subsubsection{Inelastic Neutron Scattering Spectroscopy}

As discussed in section 2.1.3, there are few published studies on burned bones using INS spectroscopy, which is partly due to the fact that this is not a routine technique since it requires access to neutron beam generating facilities (either at spallation sources or nuclear reactors). Hence, its application to the investigation of burned bones aims at gaining access to the complete vibrational profile of the samples (both unburned and burned), allowing to detect particular features that are unavailable to optical (routine) vibrational techniques. This has been shown to be key for a thorough evaluation and understanding of heat-induced structural and chemical changes in bone 
as a function of temperature. INS is a valuable tool to this purpose because, as cited, the intensity of each band is directly proportional to the number of scattering atoms being easier to distinguish between samples burned at close temperatures. Thus, there are no ratios, indexes or other calculations developed to measure parameters through INS spectra, spectrum analysis is based on peaks assignment according to Table 1 and direct comparison.

Marques et al. (56) observed that with an increase in temperature the $\mathrm{OH}^{-}$libration band, at $650 \mathrm{~cm}^{-1}$, gets narrower. Taylor et al. (96) observed a broadening of the $\mathrm{OH}^{-}$libration band with the decrease of crystallinity, from reference to commercial hydroxyapatite, to bone samples, and related it to carbonate substitution. As a consequence of heating carbonate content is progressively lost and concomitantly crystallinity increases the narrowing of the $\mathrm{OH}^{-}$libration band thus being indirectly related to the increase of crystallinity. This was corroborated by Marques et al. (56), who also detected a shift of the $\mathrm{OH}^{-}$libration band to high wavenumbers and of the $\mathrm{OH}^{-}$stretching band to low frequencies, which is indicative of alterations in the $\mathrm{H}$-bond pattern within the crystal lattice, consistent with crystallinity changes. Interestingly, this shift seems to be dependent on the type of bone or sample collection location.

\subsection{Diffraction Methods}

As mentioned earlier, diffraction techniques are the most adequate to evaluate crystallinity alterations once they measure the distance between diffracting planes. Additionally, using neutrons it is also possible to localize hydrogens and differentiate between elements and even isotopes, therefore accessing chemical information apart from structural details.

For both X-ray and neutron methods, the $2 \theta$ values at each peak depend on the wavelength of the incident radiation, but the pattern of the peaks is equal for the same sample under the same conditions. The problem, especially for neutron diffraction, is that the obtained results include not only information about the diffracting planes but also information about chemical composition, possibly occurring peak overlapping.

The Rietveld refinement method is a possible approach to overcome peak overlapping in diffraction techniques (144). It is based on the calculation of a theoretical linear profile based on a least squares approach, until the calculated profile matches the experimental one as much as possible $(37,145-147)$.

\subsubsection{X-Ray Powder Diffraction}

The crystallinity index calculation by X-ray powder diffraction was first proposed by Person et al. (33) and it is based on the reflections of the planes (211), (112), (300) and (202), according to the relationship: 


$$
\mathrm{CI}=(\mathrm{a}+\mathrm{b}+\mathrm{c}) / \mathrm{h}=\frac{H(202)+H(300)+H(112)}{H(211)}
$$

$\mathrm{a}, \mathrm{b}$ and $\mathrm{c}$ representing the difference between the maximum intensity of the reflection peaks (112), (300) and (202) and the minimum at lower $\theta$ value, respectively, while $h$ is the maximum intensity of the peak (211) (see Figure 7). This calculation must be related to the Scherrer equation, that establishes a connection between peak width and the crystal size effect (72):

$$
\mathrm{L}=\frac{K \lambda}{\beta \cos \theta}
$$

$\mathrm{L}$ being the mean dimension of the crystals along an axis perpendicular to the $h k l$ system considered (expressed in $\AA$ ), $\beta$ is the FWHM of the peak related to the reflecting plane under consideration, $K$ represents the Scherrer constant, $\lambda$ is the wavelength of the X-ray beam (in $\AA$ ) and $\theta$ is the value of the angle at the peak arises (in radians). When applying the Scherrer equation to hydroxyapatite, two single peaks are used, (002) and/or (310), the former providing information on length of the crystals (c-axis) and the latter on its thickness (perpendicular to the $c$-axis) (123).

According to Rogers and Daniels (65), at temperatures below $600{ }^{\circ} \mathrm{C}$ diffraction peaks are broadened, as expected, indicating a considerable disorder within the lattice. Between 600 and $800^{\circ} \mathrm{C}$ the most significant alterations in crystallinity occur, while above $800^{\circ} \mathrm{C}$ the crystal size, lattice parameters and microstrain attain a constant value. Piga et al. (66) observed $\mathrm{CaO}$ appearance at $775^{\circ} \mathrm{C}$, its signal increasing up to $1000^{\circ} \mathrm{C}$. In turn, Rogers and Daniels (37) suggested that the temperature at which $\mathrm{CaO}$ is detected might depend on the age of the individual. As for $\beta$-TCP advent, it was found to be sporadic, at temperatures above $1000{ }^{\circ} \mathrm{C}$.

Although XRPD is still considered the golden standard to assess crystallinity and crystal size alterations, it is not very appropriate for intact bone samples (not subject to heat), due to their highly anisotropic nature (65) that causes highly broadened peaks often leading to overlap. However, it is possible to calculate L using the peaks ascribed to the (002) and (310) scattering planes $(33,123)$. The $(002)$ diffraction peak, in particular, is especially useful as it is hardly affected by signal overlapping (65).

\subsubsection{Neutron diffraction}

As previously mentioned, neutron diffraction has been barely applied to the study of burned bones. At low burning temperatures, it is expected to yield broadened and ill-defined peaks (similarly to XRPD) due to crystal disorder and the presence of organic constituents. At temperatures above $600{ }^{\circ} \mathrm{C}$, however, very good quality data is foreseen, providing invaluable information on the sample's structure, including the localization of the hydrogen atoms, which is crucial in bone analysis. 
A few studies are found in the literature focusing on the characterization of bone tissue and characterization of synthetic apatite that might be applicable. Benmarouane et al. (148) calculated the crystallinity index based on neutron diffraction data, using the peak corresponding to the (111) plane,

$$
\mathrm{CI}=\mathrm{H}(111)_{\text {bone }} / \mathrm{H}(111)_{\text {hydroxyapatite }}
$$

$\mathrm{H}(111)_{\text {bone }}$ and $\mathrm{H}(111)_{\text {hydroxyapatite }}$ representing the intensity of the (111) diffraction peak in bone and hydroxyapatite diffraction data, respectively. The final goal of this study was to evaluate changes in bone texture caused by the heat treatment used to remove the organic matrix, the (111) peak intensity having been found not to change significantly upon 3 days heating at $625^{\circ} \mathrm{C}$. This allows us to conclude that the (111) diffracting plane may not be a good reference to assess alerations in the crystal lattice of burned bones.

Some other studies have used the diffracting planes (002) and (300) to evaluate crystalite orientation through analysis along the $c$-axis and $a$-axis, respectively $(51,121,122,149)$. Pieters et al. (121) suggest that the $a$-axis is dependent on type A carbonate content, resulting in the broadening of the (300) diffraction peak with its increase within the lattice, the carbonate presence leading to an $a$-axis expansion and a $c$-axis contraction. On the other hand, according to Bazin $e t$ al (150) the type B carbonate content within the latice prompts a contraction of the $a$-axis and an expansion of the $c$-axis, with a consequent broadening of the (002) peak. Therefore, it is expected that both (002) and (300) diffraction peaks get narrower with a temperature increase and consequent loss of carbonate (Table 3).

Besides crystal orientation and shape, neutron diffraction is highly useful to provide information about the position of ions within the bone lattice (146), with a particular ability to follow the appearance of new inorganic phases (such as $\beta$-TCP, still ill-understood).

Table 3 comprises several parameters used in bone analysis, calculated from X-ray and neutron diffraction data.

Table 4 summarizes the information provided by all the spectroscopic and diffraction parameters previously discussed, as well as heat-induced spectral/diffractogram alterations.

\section{Conclusion}

Macroscopic changes observed in burned bones may reflect submicroscopic variations caused by the burning process. It is therefore, essential to understand these submicroscopic alterations and relate them with bone warping, dimensional changes, fractures and color changes, in order to develop accurate methods for analysis of burned bones that will enable: (i) reliable 
biological profile estimation; (ii) trustworthy identification of injuries and pathologies; (iii) and assess the circumstances of death and of the pre-burning conditions of the skeletal remains.

The vibrational spectroscopy and diffraction methodologies discussed in this review intend to provide complementary evidence regarding the alterations undergone by bones when exposed to heat, adding to the existing reported information. It is therefore crucial to determine which are the most adequate techniques for a daily analysis in forensic laboratories (as well as in archaeological settings, in situ). Coupling all information gathered by several techniques vibrational spectroscopy and diffraction (X-ray and neutron based) - will hopefully lead to the identification of indicative markers for each burning condition (e.g. temperature) and to the development of a straightforward routine method for osteometric analysis of burned human skeletal remains - predictably FTIR - that will allow to relate heat-induced bone diagenesis to preburned dimensions. This approach will be of undisputable usefulness in archaeological and forensic sciences.

\section{Acknowledgement}

The authors acknowledge financial support from the Portuguese Foundation for Science and Technology - UID/MULTI/00070/2013; SFRH/BPD/84268/2012 and PTDC/IVC-ANT/1201/2014.

A special acknowledgement to Prof. J. C. Otero (University of Málaga, Spain) and to Prof. F.P.S.C. Gil (University of Coimbra, Portugal).

\section{References}

1. World Health Organization. (2011) Burn Prevention: success stories and lessons learned. Available at: http://apps.who.int/iris/bitstream/10665/97938/1/9789241501187_eng.pdf (accessed 22 October 2016).

2. Ubelaker, D. H. (2009) The forensic evaluation of burned skeletal remains: A synthesis. Forensic Sci. Int. 183 (1-3): 1-5.

3. Schwark, T., Heinrich, A., Preuße-Prange, A., and Von Wurmb-Schwark, N. (2011) Reliable genetic identification of burnt human remains. Forensic Sci. Int. Genet. 5 (5): 393399.

4. Andersen, L., Juhl, M., Solheim, T., and Borrman, H. (1995) Odontological identification of fire victims - potentialities and limitations. Int. J. Legal Med. 107 (5): 229-234.

5. Woisetschläger, M., Lussi, A., Persson, A., and Jackowski, C. (2011) Fire victim identification by post-mortem dental CT: Radiologic evaluation of restorative materials after 
exposure to high temperatures. Eur. J. Radiol. 80 (2): 432-440.

6. Thompson, T. J. U. (2016) Anthropology: Cremated Bones - Anthropology. In Encyclopedia of Forensic and Legal Medicine, Elsevier, pp 177-182.

7. Zgonjanin, D., Petković , S., Maletin, M., Vuković , R., and Drašković , D. (2015) Case report: DNA identification of burned skeletal remains. Forensic Sci. Int. Genet. Suppl. Ser. 5: e444-e446.

8. Harbeck, M., Schleuder, R., Schneider, J., Wiechmann, I., Schmahl, W. W., and Grupe, G. (2011) Research potential and limitations of trace analyses of cremated remains. Forensic Sci. Int. 204 (1-3): 191-200.

9. Blau, S., and Briggs, C. A. (2011) The role of forensic anthropology in Disaster Victim Identification (DVI). Forensic Sci. Int. 205 (1-3): 29-35.

10. Cattaneo, C. (2007) Forensic anthropology: developments of a classical discipline in the new millennium. Forensic Sci. Int. 165 (2-3): 185-193.

11. Iș can, M. Y. (2001) Global forensic anthropology in the $21^{\text {st }}$ century. Forensic Sci. Int. 117 (1-2): $1-6$.

12. Iş can, M. Y. (2005) Forensic anthropology of sex and body size. Forensic Sci. Int. 147 (23): $107-112$.

13. Steyn, M., and Patriquin, M. L. (2009) Osteometric sex determination from the pelvisDoes population specificity matter? Forensic Sci. Int. 191 (1-3): 113.e1-113.e5.

14. Thompson, T. J. U. (2004) Recent advances in the study of burned bone and their implications for forensic anthropology. Forensic Sci. Int. 146: S203-S205.

15. Thompson, T. J. U., and Chudek, J. A. (2007) A novel approach to the visualisation of heatinduced structural change in bone. Sci. Justice 47 (2): 99-104.

16. de Becdelievre, C., Thiol, S., Santos, F., and Rottier, S. (2015) From fire-induced alterations on human bones to the original circumstances of the fire: An integrated approach of human cremains drawn from a Neolithic collective burial. J. Archaeol. Sci. Reports 4: 210-225.

17. Gonçalves, D., Thompson, T. J. U., and Cunha, E. (2011) Implications of heat-induced changes in bone on the interpretation of funerary behaviour and practice. J. Archaeol. Sci. 38 (6): 1308-1313.

18. Castillo, R. F., Ubelaker, D. H., Acosta, J. A. L., and de la Fuente, G. A. C. (2013) Effects of temperature on bone tissue. Histological study of the changes in the bone matrix. Forensic 
Sci. Int. 226 (1-3): 33-37.

19. Baby, R. S. (1954) Hopowell Cremation Practices. Ohio Hist. Soc. Pap. Archaeol. 1 (1): 1-7.

20. Binford, L. R. (1963) An Analysis of Cremations from three Michigan Sites. Wisconsin Archaeol. 44: 98-110.

21. Gejvall, N. G. (1955) The Cremations at Vallhagar. In Vallhagar, a Migration Period Settlement on Gotland, Sweden, Stenberger, M., Klindt-Jensen, O., Eds., Kopenhagen: Munkgaard, pp 700-723.

22. Dokladal, M. (1962) Uber die Moglichkeiten der Identifikation von Knochen aus Leichenbranden. Mitteilungen der Sekt. Anthropol. (6): 15.

23. Gejvall, N. G. (1969) Cremations. In Science in Archaeology, Brothwell, D., Higgs, E., Clark, G., Eds., pp 468-479.

24. Wells, C. (1960) A study of cremation. Antiquity 34: 29-37.

25. Gonçalves, D., Cunha, E., and Thompson, T. J. U. (2014) Estimation of the pre-burning condition of human remains in forensic contexts. Int. J. Legal Med. 129 (5): 1137-1143.

26. Keough, N., L'Abbé, E. N., Steyn, M., and Pretorius, S. (2015) Assessment of skeletal changes after post-mortem exposure to fire as an indicator of decomposition stage. Forensic Sci. Int. 246: 17-24.

27. Pérez, L., Sanchis, A., Hernández, C. M., Galván, B., Sala, R., and Mallol, C. (2017) Hearths and bones: An experimental study to explore temporality in archaeological contexts based on taphonomical changes in burnt bones. J. Archaeol. Sci. Reports 11: 287-309.

28. Vassalo, A. R., Cunha, E., de Carvalho, L. A. E. B., and Gonçalves, D. (2016) Rather yield than break: assessing the influence of human bone collagen content on heat-induced warping through vibrational spectroscopy. Int. J. Legal Med. 130 (6): 1647-1656.

29. Reidsma, F. H., van Hoesel, A., van Os, B. J. H., Megens, L., and Braadbaart, F. (2016) Charred bone: Physical and chemical changes during laboratory simulated heating under reducing conditions and its relevance for the study of fire use in archaeology. J. Archaeol. Sci. Reports 10: 282-292.

30. Thompson, T. J. U., Islam, M., Piduru, K., and Marcel, A. (2011) An investigation into the internal and external variables acting on crystallinity index using Fourier Transform Infrared Spectroscopy on unaltered and burned bone. Palaeogeogr. Palaeoclimatol. Palaeoecol. 299 (1-2): 168-174. 
31. Shahack-Gross, R., Bar-Yosef, O., and Weiner, S. (1997) Black-Coloured Bones in Hayonim Cave, Israel: Differentiating Between Burning and Oxide Staining. J. Archaeol. Sci. 24 (5): 439-446.

32. Stiner, M., Kuhn, S., Weiner, S., and Bar-Yosef, O. (1995) Differential burning, recrystallization, and fragmentation of archaeological bone. J. Archaeol. Sci. 22: 223-237.

33. Person, A., Bocherens, H., Saliège, J.-F., Paris, F., Zeitoun, V., and Gérard, M. (1995) Early Diagenetic Evolution of Bone Phosphate : An X-ray Diffractometry Analysis. J. Archaeol. Sci. 22 (2): 211-221.

34. Pestle, W. J., Ahmad, F., Vesper, B. J., Cordell, G. A., and Colvard, M. D. (2014) Ancient bone collagen assessment by hand-held vibrational spectroscopy. J. Archaeol. Sci. 42 (1): 381389.

35. Ellingham, S. T. D., Thompson, T. J. U., and Islam, M. (2016) The Effect of Soft Tissue on Temperature Estimation from Burnt Bone Using Fourier Transform Infrared Spectroscopy. J. Forensic Sci. 61: 153-159.

36. Piga, G., Baró, M. D., Escobal, I. G., Gonçalves, D., Makhoul, C., Amarante, A., Malgosa, A., Enzo, S., and Garroni, S. (2016) A structural approach in the study of bones: fossil and burnt bones at nanosize scale. Appl. Phys. A 122 (12): 1031.

37. Piga, G., Gonçalves, D., Thompson, T. J. U., Brunetti, A., Malgosa, A., and Enzo, S. (2016) Understanding the Crystallinity Indices Behavior of Burned Bones and Teeth by ATR-IR and XRD in the Presence of Bioapatite Mixed with Other Phosphate and Carbonate Phases. Int. J. Spectrosc. 2016: 1-9.

38. Gilpin, M., and Christensen, A. M. (2015) Elemental Analysis of Variably Contaminated Cremains Using X-ray Fluorescence Spectrometry. J. Forensic Sci. 60 (4): 974-978.

39. France, C. A. M., Thomas, D. B., Doney, C. R., and Madden, O. (2014) FT-Raman spectroscopy as a method for screening collagen diagenesis in bone. J. Archaeol. Sci. 42 (1): 346-355.

40. Lee, C. L., and Einhorn, T. A. (2001) The Bone Organ System - Form and Function. In Osteoporosis, Marcus, R., Feldman, D., Kelsey, J., Eds., Academic Press, pp 3-20.Second edi.

41. Boskey, J. A., Gokhale, A. L., and Robey, P. G. (2001) The Biochemistry of Bone. In Osteoporosis, Marcus, R., Feldman, D., Kelsey, J., Eds., Academic Press, pp 107-188.Second edi. 
42. Thompson, T. J. U. (2015) The Analysis of Heat-Induced Crystallinity Change in Bone. In The Analysis of Burned Human Remains, Schmidt, C.W., Symes, S.A., Eds., pp 323-337.

43. Wang, X. Y., Zuo, Y., Huang, D., Hou, X. D., and Li, Y. B. (2010) Comparative study on inorganic composition and crystallographic properties of cortical and cancellous bone. Biomed. Environ. Sci. 23 (6): 473-480.

44. Clarke, B. (2008) Normal Bone Anatomy and Physiology. Clin. J. Am. Soc. Nephrol. 3: S131S139.

45. LeGeros, R. Z., Trautz, O. R., Klein, E., and LeGeros, J. P. (1969) Two types of carbonate substitution in the apatite structure. Experientia 25 (1): 5-7.

46. Rey, C., Collins, B., Goehl, T., Dickson, I. R., and Glimcher, M. J. (1989) The carbonate environment in bone mineral: A resolution-enhanced fourier transform infrared spectroscopy study. Calcif. Tissue Int. 45 (3): 157-164.

47. Astala, R., and Stott, M. J. (2005) First principles investigation of mineral component of bone: $\mathrm{CO}_{3}$ substitutions in hydroxyapatite. Chem. Mater. 17 (16): 4125-4133.

48. Snoeck, C., Lee-Thorp, J. A., and Schulting, R. J. (2014) From bone to ash: Compositional and structural changes in burned modern and archaeological bone. Palaeogeogr. Palaeoclimatol. Palaeoecol. 416: 55-68.

49. Wopenka, B., and Pasteris, J. D. (2005) A mineralogical perspective on the apatite in bone. Mater. Sci. Eng. C 25 (2): 131-143.

50. Munro, L. E., Longstaffe, F. J., and White, C. D. (2007) Burning and boiling of modern deer bone: Effects on crystallinity and oxygen isotope composition of bioapatite phosphate. Palaeogeogr. Palaeoclimatol. Palaeoecol. 249 (1-2): 90-102.

51. Bacon, G. E. (1990) The dependence of human bone texture on life style. Proc. R. Soc. London 240: $363-370$.

52. Gómez-Morales, J., Iafisco, M., Delgado-López, J. M., Sarda, S., and Drouet, C. (2013) Progress on the preparation of nanocrystalline apatites and surface characterization: Overview of fundamental and applied aspects. Prog. Cryst. Growth Charact. Mater. 59 (1): 146.

53. Beasley, M. M., Bartelink, E. J., Taylor, L., and Miller, R. M. (2014) Comparison of transmission FTIR, ATR, and DRIFT spectra: Implications for assessment of bone bioapatite diagenesis. J. Archaeol. Sci. 46 (1): 16-22. 
54. Trueman, C. N., Privat, K., and Field, J. (2008) Why do crystallinity values fail to predict the extent of diagenetic alteration of bone mineral? Palaeogeogr. Palaeoclimatol. Palaeoecol. 266 (3-4): 160-167.

55. Trueman, C. N. G., Behrensmeyer, A. K., Tuross, N., and Weiner, S. (2004) Mineralogical and compositional changes in bones exposed on soil surfaces in Amboseli National Park, Kenya: Diagenetic mechanisms and the role of sediment pore fluids. J. Archaeol. Sci. 31 (8): 721-739.

56. Marques, M. P. M., Gonçalves, D., Amarante, A. I. C., Makhoul, C. I., Parker, S. F., and Batista de Carvalho, L. A. E. (2016) Osteometrics in burned human skeletal remains by neutron and optical vibrational spectroscopy. RSC Adv. 6 (73): 68638-68641.

57. Etok, S. E., Valsami-Jones, E., Wess, T. J., Hiller, J. C., Maxwell, C. A., Rogers, K. D., Manning, D. A. C., White, M. L., Lopez-Capel, E., Collins, M. J., Buckley, M., Penkman, K. E. H., and Woodgate, S. L. (2007) Structural and chemical changes of thermally treated bone apatite. J. Mater. Sci. 42 (23): 9807-9816.

58. Thompson, T. J. U., Islam, M., and Bonniere, M. (2013) A new statistical approach for determining the crystallinity of heat-altered bone mineral from FTIR spectra. J. Archaeol. Sci. 40 (1): 416-422.

59. Shipman, P., Foster, G., and Schoeninger, M. (1984) Burnt bones and teeth: an experimental study of color, morphology, crystal structure and shrinkage. J. Archaeol. Sci. 11 (4): 307-325.

60. Nicholson, R. A. (1993) A Morphological Investigation of Burnt Animal Bone and an Evaluation of its Utility in Archaeology. J. Archaeol. Sci. 20: 411-428.

61. Thurner, P. J. (2016) Commentary on: Mechanical properties of cortical bone and their relationships with age, gender, composition and microindentation properties in the elderly. Bone 87: 159-160.

62. Penel, G., Leroy, G., Rey, C., and Bres, E. (1998) MicroRaman Spectral Study of the PO 4 and CO 3 Vibrational Modes in Synthetic and Biological Apatites. Calcif. Tissue Int. 63 (6): $475-481$.

63. Pasteris, J. D., Wopenka, B., Freeman, J. J., Rogers, K., Valsami-Jones, E., Van Der Houwen, J. A. M., and Silva, M. J. (2004) Lack of OH in nanocrystalline apatite as a function of degree of atomic order: Implications for bone and biomaterials. Biomaterials 25 (2): 229-238. 
64. Miller, L. M., Vairavamurthy, V., Chance, M. R., Mendelsohn, R., Paschalis, E. P., Betts, F., and Boskey, a L. (2001) In situ analysis of mineral content and crystallinity in bone using infrared micro-spectroscopy of the $\mathrm{v}_{4}\left(\mathrm{PO}_{4}{ }^{3-}\right)$ vibration. Biochim. Biophys. Acta 1527 (12): $11-19$.

65. Rogers, K. D., and Daniels, P. (2002) An X-ray diffraction study of the effects of heat treatment on bone mineral microstructure. Biomaterials 23 (12): 2577-2585.

66. Piga, G., Thompson, T. J. U., Malgosa, A., and Enzo, S. (2009) The Potential of X-Ray Diffraction in the Analysis of Burned Remains from Forensic Contexts. J. Forensic Sci. 54 (3): 534-539.

67. Rogers, K., Beckett, S., Kuhn, S., Chamberlain, A., and Clement, J. (2010) Contrasting the crystallinity indicators of heated and diagenetically altered bone mineral. Palaeogeogr. Palaeoclimatol. Palaeoecol. 296 (1-2): 125-129.

68. Piga, G., Santos-Cubedo, A., Brunetti, A., Piccinini, M., Malgosa, A., Napolitano, E., and Enzo, S. (2011) A multi-technique approach by XRD, XRF, FT-IR to characterize the diagenesis of dinosaur bones from Spain. Palaeogeogr. Palaeoclimatol. Palaeoecol. 310 (1-2): 92-107.

69. Kuzel, A. R., Christensen, A. M., and Marvin, S. M. (2016) Calcium and Phosphorus Detection Using Benchtop Versus Handheld X-ray Fluorescence Spectrometers. J. Forensic Sci. 61 (January): 190-192.

70. Zimmerman, H. A., Meizel-Lambert, C. J., Schultz, J. J., and Sigman, M. E. (2015) Chemical Differentiation of Osseous, Dental, and Non-skeletal Materials in Forensic Anthropology using Elemental Analysis. Sci. Justice 55 (2): 131-138.

71. Lozano, L., Pena-Rico, M., Heredia, a, Ocotlan-Flores, J., Gomez-Cortes, a, Velazquez, R., Belio, I., and Bucio, L. (2003) Thermal analysis study of human bone. J. Mater. Sci. 38: 4777-4782.

72. Reyes-Gasga, J., Martínez-Piñeiro, E. L., Rodríguez-Álvarez, G., Tiznado-Orozco, G. E., García-García, R., and Brès, E. F. (2013) XRD and FTIR crystallinity indices in sound human tooth enamel and synthetic hydroxyapatite. Mater. Sci. Eng. C 33 (8): 4568-4574.

73. Holden, J. L., Phakey, P. P., and Clement, J. G. (1995) Scanning electron microscope observations of heat-treated human bone. Forensic Sci. Int. 74 (1-2): 29-45.

74. King, C. L., Tayles, N., and Gordon, K. C. (2011) Re-examining the chemical evaluation of diagenesis in human bone apatite. J. Archaeol. Sci. 38 (9): 2222-2230. 
75. Reznikov, N., Chase, H., Brumfeld, V., Shahar, R., and Weiner, S. (2015) The 3D structure of the collagen fibril network in human trabecular bone: Relation to trabecular organization. Bone 71 (November): 189-195.

76. Rey, C., Miquel, J. L., Facchini, L., Legrand, A. P., and Glimcher, M. J. (1995) Hydroxyl groups in bone mineral. Bone 16 (5): 583-586.

77. Boschin, F., Zanolli, C., Bernardini, F., Princivalle, F., and Tuniz, C. (2015) A look from the inside: MicroCT analysis of burned bones. Ethnobiol. Lett. 6 (2): 258-266.

78. Imaizumi, K., Taniguchi, K., and Ogawa, Y. (2014) DNA survival and physical and histological properties of heat-induced alterations in burnt bones. Int. J. Legal Med. 128 (3): 439-446.

79. Baier, W., Norman, D. G., Warnett, J. M., Payne, M., Harrison, N. P., Hunt, N. C. A., Burnett, B. A., and Williams, M. A. (2017) Novel application of three-dimensional technologies in a case of dismemberment. Forensic Sci. Int. 270: 139-145.

80. Tu, A. (1982) Raman Spectrosopy in Biology Principles and applications. John Wiley \& Sons, Inc.

81. Stuart, B. (2005) Infrared Spectroscopy. In Kirk-Othmer Encyclopedia of Chemical Technology, John Wiley \& Sons, Inc., pp 1-20.

82. Griffiths, P. R. (2006) Introduction to Vibrational Spectroscopy. In Handbook of Vibrational Spectroscopy, John Wiley \& Sons, Ltd, pp 33-43.

83. Coates, J. (2006) Interpretation of Infrared Spectra, A Practical Approach. In Encyclopedia of Analytical Chemistry, Meyers, R.A., Ed., John Wiley \& Sons, Ltd, pp 1-23.

84. Stuart, B. (1997) Biological Applications of Infrared Spectroscopy. Ando, D.J., Ed. John Wiley \& Sons, Inc.

85. Shurvell, H. F. (2006) Spectra- Structure Correlations in the Mid- and Far-Infrared. In Handbook of Vibrational Spectroscopy, Chalmers, J.M., Ed., John Wiley \& Sons, Ltd, pp 17831816.

86. Thompson, T. J. U., Gauthier, M., and Islam, M. (2009) The application of a new method of Fourier Transform Infrared Spectroscopy to the analysis of burned bone. J. Archaeol. Sci. 36 (3): 910-914.

87. Surovell, T. A., and Stiner, M. C. (2001) Standardizing Infra-red Measures of Bone Mineral Crystallinity: an Experimental Approach. J. Archaeol. Sci. 28 (6): 633-642. 
88. Khoshhesab, Z. M. (2012) Reflectance IR Spectroscopy. In Infrared Spectroscopy - Materials Science, Engineering and Technology, Theophanides, T., Ed., InTech, pp 233-244.

89. Stathopoulou, E. T., Psycharis, V., Chryssikos, G. D., Gionis, V., and Theodorou, G. (2008) Bone diagenesis: New data from infrared spectroscopy and X-ray diffraction. Palaeogeogr. Palaeoclimatol. Palaeoecol. 266 (3-4): 168-174.

90. Gadolnik, J. (2002) ATR-FTIR Spectroscopy: Its Advantages and Limitations. Acta Chim. Slov. 49 (3): 631-642.

91. Bunaciu, A. A., Aboul-Enein, H. Y., and Fleschin, Ş . (2015) Vibrational Spectroscopy in Clinical Analysis. Appl. Spectrosc. Rev. 50 (2): 176-191.

92. Delhaye, M., and Dhamelincourt, P. (1975) Raman microprobe and microscope with laser excitation. J. Raman Spectrosc. 3 (1): 33-43.

93. Golcuk, K., Mandair, G. S., Callender, A. F., Sahar, N., Kohn, D. H., and Morris, M. D. (2006) Is photobleaching necessary for Raman imaging of bone tissue using a green laser? Biochim. Biophys. Acta 1758 (7): 868-873.

94. Maggiano, C., Dupras, T., Schultz, M., and Biggerstaff, J. (2006) Spectral and photobleaching analysis using confocal laser scanning microscopy: a comparison of modern and archaeological bone fluorescence. Mol. Cell. Probes 20 (3-4): 154-162.

95. Anastassiades, C. P., Wilson, B. C., and Song, L.-M. W. K. (2009) Fluorescence and Raman Spectroscopy. Gastrointest. Endosc. Clin. N. Am. 19 (2): 221-231.

96. Taylor, M. G., Parker, S. F., Simkiss, K., and Mitchell, P. C. H. (2001) Bone mineral: evidence for hydroxy groups by inelastic neutron scattering. Phys. Chem. Chem. Phys. 3 (8): $1514-1517$.

97. Loong, C.-K., Rey, C., Kuhn, L. T., Combes, C., Wu, Y., Chen, S.-H., and Glimcher, M. J. (2000) Evidence of hydroxyl-ion deficiency in bone apatites: an inelastic neutronscattering study. Bone 26 (6): 599-602.

98. Taylor, M. G., Parker, S. F., and Mitchell, P. C. H. (2003) A study by high energy transfer inelastic neutron scattering spectroscopy of the mineral fraction of ox femur bone. J. Mol. Struct. 651-653: 123-126.

99. Termine, J. D., and Posner, A. S. (1967) Amorphous/crystalline interrelationships in bone mineral. Calcif. Tissue Res. 1 (1): 8-23.

100. Kolosowski, K. P., Sodhi, R. N. S., Kishen, A., and Basrani, B. R. (2015) Qualitative time- 
of-flight secondary ion mass spectrometry analysis of root dentin irrigated with sodium hypochlorite, EDTA, or chlorhexidine. J. Endod. 41 (10): 1672-1677.

101. Hamed, E., Novitskaya, E., Li, J., Chen, P.-Y., Jasiuk, I., and McKittrick, J. (2012) Elastic moduli of untreated, demineralized and deproteinized cortical bone: Validation of a theoretical model of bone as an interpenetrating composite material. Acta Biomater. 8 (3): 1080-1092.

102. Termine, J. D., Eanes, E. D., Greenfield, D. J., Nylen, M. U., and Harper, R. A. (1973) Hydrazine-deproteinated bone mineral. Calcif. Tissue Res. 12 (1): 73-90.

103. Karampas, I. A., Orkoula, M. G., and Kontoyannis, C. G. (2012) Effect of hydrazine based deproteination protocol on bone mineral crystal structure. J. Mater. Sci. Mater. Med. 23 (5): 1139-1148.

104. Bertazzo, S., and Bertran, C. A. (2008) Effect of hydrazine deproteination on bone mineral phase: A critical view. J. Inorg. Biochem. 102 (1): 137-145.

105. Shea, D. A., and Morris, M. D. (2002) Bone Tissue Fluorescence Reduction for Visible Laser Raman Spectroscopy. Appl. Spectrosc. 56 (2): 182-186.

106. García-Vidal, F. J., and Pendry, J. B. (1996) Collective Theory for Surface Enhanced Raman Scattering. Phys. Rev. Lett. 77 (6): 1163-1166.

107. Laane, J. (2009) Frontiers of Molecular Spectroscopy. Laane, J., Ed. First. Elsevier B.V.

108. Haynes, Christy L., McFarland, Adam D., Van Duyne, R. P. (2005) Surface-Enhanced Raman Spectroscopy. Anal. Chem. 77 (17): 338 A-346 A.

109. Druet, S. A. J., and Taran, J.-P. E. (1981) CARS spectroscopy. Prog. Quantum Electron. 7 (1): $1-72$.

110. Parekh, S. H., Lee, Y. J., Aamer, K. A., and Cicerone, M. T. (2010) Label-Free Cellular Imaging by Broadband Coherent Anti-Stokes Raman Scattering Microscopy. Biophys. J. 99 (8): 2695-2704.

111. Krafft, C., Dietzek, B., and Popp, J. (2009) Raman and CARS microspectroscopy of cells and tissues. Analyst 134 (6): 1046-1057.

112. Pynn, R. (2009) Neutron Scattering - A Non-destructive Microscope for seeing Inside Matter. In Neutron Applications in Earth, Energy and Environmental Sciences, Liang, L., Rinaldi, R., Schober, H., Eds., Springer US, pp 1-28.

113. Mitchell, P., Parker, S., Ramirez-Cuesta, A., and Tomkinson, J. (2005) Vibrational 
Spectroscopy with Neutrons. Finney, J.L., Worcester, D.L., Eds. World Scientific Publishing Co. Pte. Ltd.

114. Parker, S. F. (2006) Inelastic Neutron Scattering Spectroscopy. In Handbook of Vibrational Spectroscopy, Chalmers, J.M., Ed., John Wiley \& Sons, Ltd, pp 837-852.

115. Hudson, B. S. (2001) Inelastic Neutron Scattering: A Tool in Molecular Vibrational Spectroscopy and a Test of ab Initio Methods. J. Phys. Chem. A 105 (16): 3949-3960.

116. Bacon, G. E. (1966) X-ray and neutron diffraction. First edit. Pergamon Press Ltd.

117. Hudson, B. S. (2006) Vibrational spectroscopy using inelastic neutron scattering: Overview and outlook. Vib. Spectrosc. 42 (1): 25-32.

118. Lefmann, K. (2007) Neutron Scattering:Theory, Instrumentation, and Simulation. Available at: http://www.fys.ku.dk/ willend/Neutron1_4.pdf (accessed 7 December 2016).

119. Cullity, B. D. (1978) Elements of X-Ray Diffraction. Cohen, M., Ed. Second edi. AddisonWesley Publishing Company, Inc.

120. Azaroff, L. V., and Buerger, M. J. (1958) The Powder Method in X-Ray Crystallography. McGraw-Hill Book Company, Inc.

121. Pieters, I. Y., De Maeyer, E. A. P., and Verbeeck, R. M. H. (1998) Influence of $\mathrm{Na}^{+}$on the Stoichiometry of Carbonated Hydroxyapatite Obtained by the Hydrolysis of Octacalcium Phosphate. Inorg. Chem. 37 (24): 6392-6395.

122. Bacon, G. E., Bacon, P. J., and Griffiths, R. K. (1979) The orientation of apatite crystals in bone. J. Appl. Crystallogr. 12 (1): 99-103.

123. Farlay, D., Panczer, G., Rey, C., Delmas, P. D., and Boivin, G. (2010) Mineral maturity and crystallinity index are distinct characteristics of bone mineral. J. Bone Miner. Metab. 28 (4): 433-445.

124. Alverez-Lloret, P., Rodriguez-Navarro, a. B., Romanek, C. S., Gaines, K. F., and Congdon, J. (2006) Quantitative Analysis of Bone Mineral Using Ftir. Macla 6: 45-47.

125. Lebon, M., Reiche, I., Bahain, J. J., Chadefaux, C., Moigne, A. M., Fröhlich, F., Sémah, F., Schwarcz, H. P., and Falguères, C. (2010) New parameters for the characterization of diagenetic alterations and heat-induced changes of fossil bone mineral using Fourier transform infrared spectrometry. J. Archaeol. Sci. 37 (9): 2265-2276.

126. Weiner, S., and Bar-Yosef, O. (1990) States of preservation of bones from prehistoric sites 
in the Near East: A survey. J. Archaeol. Sci. 17 (2): 187-196.

127. Termine, J. D., and Posner, A. S. (1966) Infrared Analysis of Rat Bone: Age Dependency of Amorphous and Crystalline Mineral Fractions. Science (80-. ). 153 (3743): 1523-1525.

128. Shemesh, A. (1990) Crystallinity and diagenesis of sedimentary apatites. Geochim. Cosmochim. Acta 54 (9): 2433-2438.

129. Pucéat, E., Reynard, B., and Lécuyer, C. (2004) Can crystallinity be used to determine the degree of chemical alteration of biogenic apatites? Chem. Geol. 205 (1-2): 83-97.

130. Ellingham, S. T. D., Thompson, T. J. U., Islam, M., and Taylor, G. (2015) Estimating temperature exposure of burnt bone - A methodological review. Sci. Justice 55 (3): 181-188.

131. Paschalis, E. P., DiCarlo, E., Betts, F., Sherman, P., Mendelsohn, R., and Boskey, A. L. (1996) FTIR microspectroscopic analysis of human osteonal bone. Calcif. Tissue Int. 59 (6): $480-7$.

132. Wright, L. E., and Schwarcz, H. P. (1996) Infrared and Isotopic Evidence for Diagenesis of Bone Apatite at Dos Pilas, Guatemala: Palaeodietary Implications. J. Archaeol. Sci. 23 (6): 933-944.

133. Sponheimer, M., and Lee-Thorp, J. a. (1999) Alteration of Enamel Carbonate Environments during Fossilization. J. Archaeol. Sci. 26 (2): 143-150.

134. Holcomb, D. W., and Young, R. A. (1980) Thermal decomposition of human tooth enamel. Calcif. Tissue Int. 31 (1): 189-201.

135. Habelitz, S., Pascual, L., and Durán, A. (2001) Transformation of tricalcium phosphate into apatite by ammonia treatment. J. Mater. Sci. 36 (17): 4131-4135.

136. Zazzo, A., Lebon, M., Chiotti, L., Comby, C., Delqué-Količ , E., Nespoulet, R., and Reiche, I. (2013) Can we Use Calcined Bones for 14C Dating the Paleolithic? Radiocarbon 55 (2-3): 1409-1421.

137. Gamsjaeger, S., Hofstetter, B., Fratzl-Zelman, N., Roschger, P., Roschger, A., Fratzl, P., Brozek, W., Masic, A., Misof, B. M., Glorieux, F. H., Klaushofer, K., Rauch, F., and Paschalis, E. P. (2014) Pediatric reference Raman data for material characteristics of iliac trabecular bone. Bone 69: 89-97.

138. Roschger, A., Gamsjaeger, S., Hofstetter, B., Masic, A., Blouin, S., Messmer, P., Berzlanovich, A., Paschalis, E. P., Roschger, P., Klaushofer, K., and Fratzl, P. (2014) Relationship between the $\mathrm{v}_{2} \mathrm{PO}_{4}$ /amide III ratio assessed by Raman spectroscopy and the 
calcium content measured by quantitative backscattered electron microscopy in healthy human osteonal bone. J. Biomed. Opt. 19 (6): 65002.

139. Gamsjaeger, S., Masic, A., Roschger, P., Kazanci, M., Dunlop, J. W. C., Klaushofer, K., Paschalis, E. P., and Fratzl, P. (2010) Cortical bone composition and orientation as a function of animal and tissue age in mice by Raman spectroscopy. Bone 47 (2): 392-399.

140. Kazanci, M., Roschger, P., Paschalis, E. P., Klaushofer, K., and Fratzl, P. (2006) Bone osteonal tissues by Raman spectral mapping: Orientation-composition. J. Struct. Biol. 156 (3): 489-496.

141. Akkus, O., Adar, F., and Schaffler, M. B. (2004) Age-related changes in physicochemical properties of mineral crystals are related to impaired mechanical function of cortical bone. Bone 34 (3): 443-453.

142. Thomas, D. B., McGoverin, C. M., Fordyce, R. E., Frew, R. D., and Gordon, K. C. (2011) Raman spectroscopy of fossil bioapatite - A proxy for diagenetic alteration of the oxygen isotope composition. Palaeogeogr. Palaeoclimatol. Palaeoecol. 310 (1-2): 62-70.

143. McCreadie, B. R., Morris, M. D., Chen, T., Sudhaker Rao, D., Finney, W. F., Widjaja, E., and Goldstein, S. A. (2006) Bone tissue compositional differences in women with and without osteoporotic fracture. Bone 39 (6): 1190-1195.

144. Sakata, M., and Cooper, M. J. (1979) An analysis of the Rietveld refinement method. J. Appl. Crystallogr. 12 (6): 554-563.

145. Leventouri, T., Antonakos, A., Kyriacou, A., Venturelli, R., Liarokapis, E., and Perdikatsis, V. (2009) Crystal Structure Studies of Human Dental Apatite as a Function of Age. Int. J. Biomater. 2009: 1-6.

146. Wilson, R. M., Elliott, J. C., Dowker, S. E. P., and Smith, R. I. (2004) Rietveld structure refinement of precipitated carbonate apatite using neutron diffraction data. Biomaterials 25 (11): $2205-2213$.

147. Leventouri, T., Chakoumakos, B. C., Papanearchou, N., and Perdikatsis, V. (2001) Comparison of Crystal Structure Parameters of Natural and Synthetic Apatites from Neutron Powder Diffraction. J. Mater. Res. 16 (9): 2600-2606.

148. Benmarouane, A., Hansen, T., and Lodini, A. (2004) Heat treatment of bovine bone preceding spatially resolved texture investigation by neutron diffraction. Phys. B Condens. Matter 350 (1-3): 611-614.

149. Bacon, G. E., Bacon, P. J., and Griffiths, R. K. (1977) The study of bones by neutron 
diffraction. J. Appl. Crystallogr. 10 (2): 124-126.

150. Bazin, D., Chappard, C., Combes, C., Carpentier, X., Rouzière, S., André, G., Matzen, G., Allix, M., Thiaudière, D., Reguer, S., Jungers, P., and Daudon, M. (2009) Diffraction techniques and vibrational spectroscopy opportunities to characterise bones. Osteoporos. Int. 20 (6): 1065-1075. 


\section{List of captions}

Figure 1. Main chemical substitutions in crystal lattice of bioapatite.

Figure 2. Schematic representation of heat-induced changes in human bone, for the temperature range 25 to $1000{ }^{\circ} \mathrm{C}$. Upper part: color alterations. Lower part: submicroscopic variations.

Symbols: loss $\downarrow$; appearance $\uparrow$; decrease ${ }^{\downarrow}$; increase $\uparrow$; organic matrix ${ }^{\mathrm{s}}$; crystal thickness and length ${ }^{3}$; intercrystallite space $)$.

Figure 3. Schematic representation of an FTIR-ATR experiment.

Figure 4. Schematic representation of the vibrational transitions corresponding to IR absorption and light scattering - Rayleigh and Raman (Stokes and anti-Stokes).

Figure 5. Representation of the vibrational transitions involved in the CARS process.

Figure 6. Schematic representation of FTIR spectra of bone samples in the range $450-700 \mathrm{~cm}^{-1}$, related to the crystallinity index calculation.

Figure 7. Schematic representation of the diffraction peaks involved in the crystallinity index calculation.

Table 1. Main infrared (IR), Raman and inelastic neutron scattering (INS) wavenumbers for human bone samples.

Table 2. Quantitative relationships for assessing heat induced alterations in bone, based on FTIR and Raman data.

Table 3. Quantitative relationships based on X-ray and neutron diffraction techniques, established to assess heat induced alterations in bone.

Table 4. Summary of spectroscopic parameters related to heat induced alterations in bone, based on vibrational spectroscopy and diffraction techniques. 


\section{List of captions}

Figure 1. Main chemical substitutions in bioapatite's crystal lattice.

Figure 2. Schematic representation of heat-induced changes in human bone, for the temperature range 25 to $1000{ }^{\circ} \mathrm{C}$. Upper part: color alterations. Lower part: submicroscopic variations.

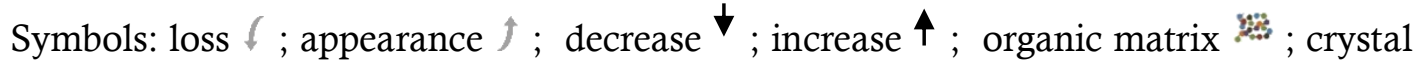
thickness and length ; intercrystallite space $)$.

Figure 3. Schematic representation of an FTIR-ATR experiment.

Figure 4. Schematic representation of the vibrational transitions corresponding to IR absorption and light scattering - Rayleigh and Raman (Stokes and anti-Stokes).

Figure 5. Representation of the vibrational transitions involved in the CARS process.

Figure 6. Schematic representation of FTIR spectra of bone samples in the range $450-700 \mathrm{~cm}^{-1}$, related to the crystallinity index calculation.

Figure 7. Schematic representation of the diffraction peaks involved in the crystallinity index calculation.

Table 1. Main infrared (IR), Raman and inelastic neutron scattering (INS) wavenumbers for human bone samples.

Table 2. Quantitative relationships for assessing heat induced alterations in bone, based on FTIR and Raman data.

Table 3. Quantitative relationships based on X-ray and neutron diffraction techniques, established to assess heat induced alterations in bone.

Table 4. Summary of spectroscopic parameters related to heat induced alterations in bone, based on vibrational spectroscopy and diffraction techniques. 
Table 1. Main infrared (IR), Raman and inelastic neutron scattering (INS) wavenumbers for human bone samples.

\begin{tabular}{|c|c|c|c|c|}
\hline IR & Raman & INS & Assignment & Reference \\
\hline & & 4246 & $\operatorname{Comb}(\mathrm{OH}$ libration $+v(\mathrm{OH}))$ & (44) \\
\hline 3573 & 3572 & 3585 & $v(\mathrm{OH})(\mathrm{HAp})$ & $(30,44,89)$ \\
\hline 3300 & & 3385 & $v(\mathrm{OH})$ (water) & (44) \\
\hline \multirow[t]{2}{*}{$2960-2850$} & $\begin{array}{c}2978,2940 \\
2882\end{array}$ & 2974 & $v(\mathrm{CH})$ (lipids) & (44) \\
\hline & & 2560 & $3^{\text {rd }}$ overt (OH libration) & (44) \\
\hline \multirow[t]{2}{*}{2010} & & & $v(\mathrm{CN})_{\text {Cyanamide }}$ & $(35,115)$ \\
\hline & & 1941 & $2^{\text {nd }}$ overt (OH libration) & (44) \\
\hline 1660 & $1616-1720$ & 1665 & Amide I (collagen) & $\begin{array}{c}(44,49,116 \\
117)\end{array}$ \\
\hline 1650 & & 1650 & $\delta(\mathrm{HOH})_{\text {water }}$ & (44) \\
\hline $1540-1580$ & & 1550 & Amide II (collagen) & $(44,118)$ \\
\hline 1540 & & & $v_{3}\left(\mathrm{CO}_{3}\right)_{\mathrm{A}}$ & $(35,46)$ \\
\hline & 1003 & & Phe ring breathing & $(49,119)$ \\
\hline 1460 & $1440-1460$ & 1460 & $\delta\left(\mathrm{CH}_{2}\right)_{\text {collagen+lipids }} ; \nu_{3}\left(\mathrm{CO}_{3}\right)_{\mathrm{B}}$ & $\begin{array}{c}(25,44,120- \\
122)\end{array}$ \\
\hline 1450 & & & $v_{3}\left(\mathrm{CO}_{3}{ }^{2-}\right)_{\mathrm{A}+\mathrm{B}}$ & $(35)$ \\
\hline \multirow[t]{2}{*}{$1415-1425$} & & & $v_{3}\left(\mathrm{CO}_{3}{ }^{2-}\right)_{\mathrm{B}}$ & $(120,121)$ \\
\hline & & $1300-1310$ & $1^{\text {st }}$ overt (OH libration) & (44) \\
\hline 1242 & $1215-1320$ & 1242 & Amide III (collagen) & $(44,116,123)$ \\
\hline $1090(\mathrm{sh})$ & & & $v_{3}\left(\mathrm{PO}_{4}{ }^{3-}\right)$ (presence of francolite) & (124) \\
\hline & 1070 & & $v_{1}\left(\mathrm{CO}_{3}^{2-}\right)_{\mathrm{B}}$ & $(51,125)$ \\
\hline \multirow[t]{2}{*}{1035} & 1046 & & $v_{3}\left(\mathrm{PO}_{4}{ }^{3-}\right)$ & $(87,116,126)$ \\
\hline & 1100 & & $v_{1}\left(\mathrm{CO}_{3}^{2-}\right)_{\mathrm{A}}$ & $(51,125)$ \\
\hline 1005 & 1005 & & $v_{1}\left(\mathrm{HPO}_{4}^{2-}\right)$ & $(51,118)$ \\
\hline 960 & 960 & & $v_{1}\left(\mathrm{PO}_{4}^{3-}\right)$ & $(25,87,127)$ \\
\hline & $919,878,855$ & & Pro and Hyp (collagen) & $(119,127)$ \\
\hline
\end{tabular}




\begin{tabular}{|c|c|c|c|c|}
\hline 878 & & & $v_{2}\left(\mathrm{CO}_{3}{ }^{2-}\right)_{\mathrm{A}}$ & $(33,128,129)$ \\
\hline 872 & & & $v_{2}\left(\mathrm{CO}_{3}{ }^{2-}\right)_{\mathrm{B}}$ & $(33,128,129)$ \\
\hline 710 & & & $\mathrm{CO}\left(\mathrm{CaCO}_{3}\right)$ & (126) \\
\hline $700 w$ & & & $v_{4}\left(\mathrm{CO}_{3}{ }^{2-}\right)$ & (87) \\
\hline 700 & & & $\delta\left(\mathrm{NCN}^{2-}\right)_{\text {Cyanamide }}$ & $(35,115)$ \\
\hline 630 & & 650 & $\mathrm{OH}_{\text {libration }}(\mathrm{HAp})$ & $(44,87,130)$ \\
\hline 565,603 & $578-617$ & & $v_{4}\left(\mathrm{PO}_{4}^{3-}\right)$ & $(25,116,127)$ \\
\hline $547 s h$ & & & $\beta-\mathrm{TCP}$ & (57) \\
\hline 470 & $422-454$ & & $v_{2}\left(\mathrm{PO}_{4}{ }^{3-}\right)$ & $\begin{array}{c}(25,87,116 \\
123)\end{array}$ \\
\hline $343,355 s h$ & 329 & & $v_{3}(\mathrm{Ca}-\mathrm{OH})$ & $(131)$ \\
\hline 337 & 335 & & $\mathrm{OH}_{\text {translation }}(\mathrm{Hap})$ & $(132,133)$ \\
\hline \multirow[t]{2}{*}{$0-300$} & $0-320$ & & $\left(\mathrm{Ca}-\mathrm{PO}_{4}\right)_{\text {translation / lattice modes }} ; \mathrm{PO}_{4}^{3-}$ librational modes & $(131,132,134)$ \\
\hline & & 250 & $\mathrm{CH}_{3}$ torsion (proteins) & $(44,87)$ \\
\hline 228 & & & $v_{2}(\mathrm{Ca}-\mathrm{OH})_{\text {lattice modes }}$ & (131) \\
\hline
\end{tabular}

${ }^{*}$ sh shoulder; $w$ - weak; comb - combination mode; overt overtone; $\beta$-TCP - $\beta$-tricalcium phosphate; $\delta$ - in plane deformation; $v$ - stretching; $\left(\mathrm{CO}_{3}{ }^{2-}\right)_{\mathrm{A}}$ A type carbonate, $\left(\mathrm{CO}_{3}{ }^{2-}\right)_{\mathrm{B}} \mathrm{B}$ type carbonate. 
Table 2. Quantitative relationships for assessing heat induced alterations in bone, based on FTIR and Raman data.

\begin{tabular}{|c|c|c|c|c|}
\hline Method & \multicolumn{2}{|c|}{ Parameter } & Spectral relationship & Reference \\
\hline \multirow{3}{*}{ 舀 } & $\mathrm{CI}$ & $\begin{array}{l}\text { Cristallinity } \\
\text { Index }\end{array}$ & $\frac{A b s\left(603 \mathrm{~cm}^{-1}\right)+A b s\left(565 \mathrm{~cm}^{-1}\right)}{A b s\left(595 \mathrm{~cm}^{-1}\right)}$ & (138) \\
\hline & & $\begin{array}{l}\text { Cristallynity } \\
\text { and Maturity }\end{array}$ & $\frac{A\left(1020 \mathrm{~cm}^{-1}\right)}{A\left(1030 \mathrm{~cm}^{-1}\right)}$ & $(137,140)$ \\
\hline & $\mathrm{C} / \mathrm{P}$ & \multirow{2}{*}{$\begin{array}{l}\text { Carbonate to } \\
\text { Phosphate }\end{array}$} & $\frac{\operatorname{Abs}\left(1415 \mathrm{~cm}^{-1}\right)}{\operatorname{Abs}\left(1035 \mathrm{~cm}^{-1}\right)}$ & $\begin{array}{l}(26,46 \\
126)\end{array}$ \\
\hline \multirow{11}{*}{ 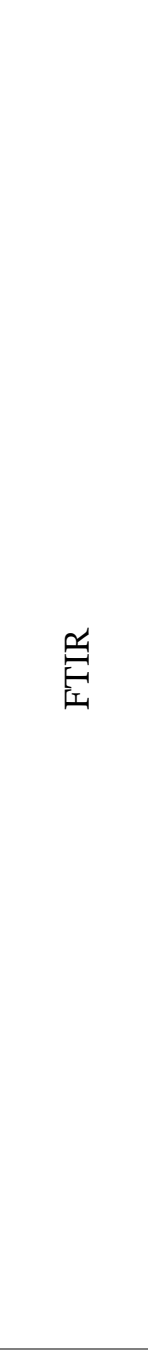 } & $\mathrm{C} / \mathrm{P}$ & & $\frac{A b s\left(1460 \mathrm{~cm}^{-1}\right)+A b s\left(1425 \mathrm{~cm}^{-1}\right)}{A b s\left(603 \mathrm{~cm}^{-1}\right)+A b s\left(565 \mathrm{~cm}^{-1}\right)}$ & (121) \\
\hline & API & $\begin{array}{l}\text { Type A } \\
\text { carbonate }\end{array}$ & $\frac{\operatorname{Abs}\left(1540 \mathrm{~cm}^{-1}\right)}{\operatorname{Abs}\left(603 \mathrm{~cm}^{-1}\right)}$ & $(35,120)$ \\
\hline & BPI & $\begin{array}{l}\text { Type B } \\
\text { carbonate }\end{array}$ & $\frac{A b s\left(1415 \mathrm{~cm}^{-1}\right)}{A b s\left(603 \mathrm{~cm}^{-1}\right)}$ & $(35,120)$ \\
\hline & $\mathrm{C} / \mathrm{C}$ & $\begin{array}{c}\text { Carbonate } \\
(\mathrm{A}+\mathrm{B}) \text { to } \\
\text { carbonate } \mathrm{B}\end{array}$ & $\frac{A b s\left(1450 \mathrm{~cm}^{-1}\right)}{A b s\left(1415 \mathrm{~cm}^{-1}\right)}$ & (35) \\
\hline & $\mathrm{OH} / \mathrm{P}$ & $\begin{array}{l}\text { Amount of } \\
\mathrm{OH}^{-} \text {groups }\end{array}$ & $\frac{\operatorname{Abs}\left(630 \mathrm{~cm}^{-1}\right)}{\operatorname{Abs}\left(603 \mathrm{~cm}^{-1}\right)}$ & (35) \\
\hline & $\mathrm{CN} / \mathrm{P}$ & $\begin{array}{l}\text { Cyanamide } \\
\text { content }\end{array}$ & $\frac{A b s\left(2010 \mathrm{~cm}^{-1}\right)}{A b s\left(1035 \mathrm{~cm}^{-1}\right)}$ & (115) \\
\hline & $\mathrm{CO} / \mathrm{P}$ & $\begin{array}{l}\text { Protein to } \\
\text { Phosphate }\end{array}$ & $\frac{A b s\left(1650 \mathrm{~cm}^{-1}\right)}{\operatorname{Abs}\left(1035 \mathrm{~cm}^{-1}\right)}$ & \\
\hline & $\mathrm{CO} / \mathrm{CO}_{3}$ & $\begin{array}{l}\text { Protein to } \\
\text { Carbonate }\end{array}$ & $\frac{\operatorname{Abs}\left(1650 \mathrm{~cm}^{-1}\right)}{A b s\left(1415 \mathrm{~cm}^{-1}\right)}$ & \\
\hline & $\mathrm{CO}_{3} / \mathrm{P}$ & $\begin{array}{l}\text { Carbonate to } \\
\text { Phosphate }\end{array}$ & $\frac{A b s\left(900 \mathrm{~cm}^{-1}\right)}{A b s\left(1035 \mathrm{~cm}^{-1}\right)}$ & (46) \\
\hline & PHT & $\begin{array}{c}\text { Phosphate } \\
\text { High } \\
\text { Temperature }\end{array}$ & $\frac{A b s\left(625 \mathrm{~cm}^{-1}\right)}{A b s\left(610 \mathrm{~cm}^{-1}\right)}$ & \\
\hline & Full width & alf maximum & FWHM $\left(1035 \mathrm{~cm}^{-1}\right)$ & \\
\hline \multirow{4}{*}{ 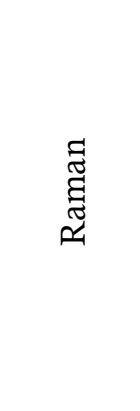 } & \multicolumn{2}{|c|}{ Relative pyridinoline content } & $\frac{I\left(1660 \mathrm{~cm}^{-1}\right)}{A(\text { amide I })}$ & \\
\hline & \multicolumn{2}{|c|}{ Relative proteoglycan content } & $\frac{A\left(1365-1390 \mathrm{~cm}^{-1}\right)}{A(\text { amide III })}$ & (123) \\
\hline & \multicolumn{2}{|c|}{ Relative lipid content } & $\frac{A\left(1298 \mathrm{~cm}^{-1}\right)}{A(\text { amide III })}$ & \\
\hline & \multicolumn{2}{|c|}{ Mineral to matrix } & $\left.\mathrm{A}\left(v_{2}\left(\mathrm{PO}_{4}{ }^{3}\right)\right)\right) / \mathrm{A}($ amide III $)$ & (123) \\
\hline
\end{tabular}




\begin{tabular}{|c|c|c|}
\hline & $\mathrm{A}\left(v_{1}\left(\mathrm{PO}_{4}^{3-}\right)\right) / \mathrm{A}($ amide $\mathrm{I})$ & (125) \\
\hline $\begin{array}{c}\text { Mineral } \\
\text { maturity/Crystallinity }\end{array}$ & $1 / \mathrm{FWHM}\left(v_{1}\left(\mathrm{PO}_{4}{ }^{3-}\right)\right)$ & (123) \\
\hline \multirow{2}{*}{$\mathrm{C} / \mathrm{P}$} & $\mathrm{A}\left(v_{1}\left(\mathrm{CO}_{3}^{2-}\right)\right) / \mathrm{A}\left(v_{1}\left(\mathrm{PO}_{4}^{3-}\right)\right)$ & (117) \\
\hline & $\mathrm{A}\left(v_{1}\left(\mathrm{CO}_{3}{ }^{2-}\right)\right) / \mathrm{A}\left(v_{2}\left(\mathrm{PO}_{4}{ }^{3-}\right)\right)$ & $(145)$ \\
\hline Collagen preservation & $I\left(v_{1}\left(\mathrm{PO}_{4}^{3-}\right)\right) / I\left(v(\mathrm{CO})_{\text {Amide } \mathrm{I}}\right)$ & (49) \\
\hline
\end{tabular}

* $A b s$ absorbance, $A$ integrated area, $I$ intensity 
Table 3. Quantitative relationships based on X-ray and neutron diffraction techniques, established to assess heat induced alterations in bone.

\begin{tabular}{|c|c|c|c|c|c|}
\hline Method & \multicolumn{2}{|c|}{ Parameter } & \multirow{2}{*}{\multicolumn{2}{|c|}{$\begin{array}{c}\text { Peak relationship } \\
\frac{H(202)+H(300)+H(112)}{H(211)}\end{array}$}} & Reference \\
\hline \multirow{3}{*}{$\mathrm{XRD}$} & \multirow{3}{*}{$\begin{array}{l}\mathrm{CI} \\
\mathrm{L}\end{array}$} & $\begin{array}{l}\text { Crystallinity } \\
\text { index }\end{array}$ & & & $(24)$ \\
\hline & & Crystal & $K \lambda$ & $\beta=F W H M(002)$ & \multirow{2}{*}{ (135) } \\
\hline & & dimension & $\mathrm{L}=\overline{\beta \cos \theta}$ & $\beta=F W H M(310)$ & \\
\hline $\begin{array}{l}\text { Neutron } \\
\text { diffraction }\end{array}$ & $\mathrm{CI}$ & $\begin{array}{l}\text { Crystallinity } \\
\text { index }\end{array}$ & \multicolumn{2}{|c|}{$\frac{H(111)_{\text {bone }}}{H(111)_{\text {hydroxyapatite }}}$} & $(152)$ \\
\hline
\end{tabular}


Table 4. Summary of spectroscopic parameters related to heat induced alterations in bone, based on vibrational spectroscopy and diffraction techniques.

\begin{tabular}{|c|c|c|c|}
\hline \multicolumn{4}{|c|}{ FTIR spectroscopy } \\
\hline & Parameter alterations & Spectral alterations & Reference \\
\hline $\mathrm{CI}$ & $\begin{array}{l}\text { Increases up to } 700-800{ }^{\circ} \mathrm{C} \text {; slightly } \\
\text { decrease at higher temperatures }\end{array}$ & Peak sharpening & (138) \\
\hline $\begin{array}{l}\mathrm{A}(1020) / \\
\mathrm{A}(1030)\end{array}$ & $\begin{array}{l}\text { Decreases with an increase in } \\
\text { temperature }\end{array}$ & $\begin{array}{l}v_{1}\left(\mathrm{PO}_{4}^{3-}\right) \text { peak shift to } \\
\text { higher frequencies }\end{array}$ & (137) \\
\hline $\mathrm{C} / \mathrm{P}$ & $\begin{array}{l}\text { Decreases with an increase in } \\
\text { temperature; significant changes at } \\
500 \text { and } 700^{\circ} \mathrm{C}\end{array}$ & $\begin{array}{l}1415 \mathrm{~cm}^{-1} \text { band intensity } \\
\text { decreases with an increase }\end{array}$ & $(26,46$ \\
\hline BPI & $\begin{array}{l}\text { Decreases with an increase in } \\
\text { temperature }\end{array}$ & in temperature & \\
\hline API & $\begin{array}{l}\text { Increases up to } 800{ }^{\circ} \mathrm{C} \text {, decreasing } \\
\text { for higher temperatures }\end{array}$ & $\begin{array}{l}\text { Peak overlapping with } \\
\text { amide II band near } \\
1540 \mathrm{~cm}^{-1} \text {, at low burning } \\
\text { temperatures }\end{array}$ & $\begin{array}{c}(35,120 \\
142)\end{array}$ \\
\hline $\mathrm{C} / \mathrm{C}$ & $\begin{array}{l}\text { Represents the carbonate } \mathrm{A}+\mathrm{B} \text { to } \\
\text { carbonate } \mathrm{B} \text { ratio (according to (35)). } \\
\text { Increases from } 600 \text { to } 900^{\circ} \mathrm{C}\end{array}$ & $\begin{array}{l}1450 \mathrm{~cm}^{-1} \text { band intensity } \\
\text { decreases with an increase } \\
\text { in temperature }\end{array}$ & (35) \\
\hline $\mathrm{OH} / \mathrm{P}$ & $\begin{array}{l}\text { Useful for samples heated above } \\
700^{\circ} \mathrm{C} \text {, increasing with an increase } \\
\text { in temperature }\end{array}$ & $\begin{array}{l}\text { An absorbance peak arrises } \\
\text { at } 630 \mathrm{~cm}^{-1}\end{array}$ & $(26,35,46)$ \\
\hline $\mathrm{CN} / \mathrm{P}$ & $\begin{array}{l}\text { Convenient for samples heated } \\
\text { above } 900{ }^{\circ} \mathrm{C} \text {; indicative of heating } \\
\text { in the presence of ammonia }\end{array}$ & $\begin{array}{l}\text { Cyanamide appearance, } \\
\text { with two typical bands at } \\
700 \mathrm{~cm}^{-1} \text { and } 2010 \mathrm{~cm}^{-1}\end{array}$ & $(35,143)$ \\
\hline $\mathrm{CO} / \mathrm{P}$ & $\begin{array}{l}\text { Useful for samples heated at low } \\
\text { temperatures }\left(<400{ }^{\circ} \mathrm{C}\right) \text {; decreases } \\
\text { with an increase in temperature }\end{array}$ & $\begin{array}{l}1650 \mathrm{~cm}^{-1} \text { band intensity } \\
\text { decreases due to collagen }\end{array}$ & \\
\hline $\mathrm{CO} / \mathrm{CO}_{3}$ & $\begin{array}{l}\text { Decreases with an increase in } \\
\text { temperature }\end{array}$ & combustion & (46) \\
\hline $\mathrm{CO}_{3} / \mathrm{P}$ & $\begin{array}{l}\text { Decreases with an increase in } \\
\text { temperature; easily affected by the } \\
v_{1}\left(\mathrm{PO}_{4}\right) \text { band broadening }\end{array}$ & $\begin{array}{l}900 \mathrm{~cm}^{-1} \text { band intensity } \\
\text { decreases due to carbonate } \\
\text { loss }\end{array}$ & \\
\hline
\end{tabular}




\begin{tabular}{|c|c|c|c|}
\hline $\mathrm{PHT}$ & $\begin{array}{l}\text { Useful for samples heated above } \\
700^{\circ} \mathrm{C} \text {; increase with an increase in } \\
\text { temperature }\end{array}$ & Peak sharpening & \\
\hline $\begin{array}{c}\text { FWHM } \\
\left(1035 \mathrm{~cm}^{-1}\right)\end{array}$ & $\begin{array}{l}\text { Useful for samples heated above } \\
700^{\circ} \mathrm{C} \text {; decrease with an increase in } \\
\text { temperature }\end{array}$ & $1035 \mathrm{~cm}^{-1}$ band sharpening & \\
\hline \multicolumn{4}{|c|}{ Raman spectroscopy } \\
\hline & Parameter alterations & Spectral alterations & Reference \\
\hline $\begin{array}{l}\text { Mineral to } \\
\text { matrix }\end{array}$ & $\begin{array}{l}\text { Increases with an increase in } \\
\text { temperature until it is impossible to } \\
\text { calculate due to collagen } \\
\text { combustion; useful for low burning } \\
\text { temperatures }\end{array}$ & $\begin{array}{l}\text { Amide I and III bands } \\
\text { intensity decrease, } \\
\text { disappearing upon collagen } \\
\text { combustion }\end{array}$ & $(123)$ \\
\hline $\begin{array}{l}\text { Mineral } \\
\text { maturity/ } \\
\text { Crystallinity }\end{array}$ & $\begin{array}{l}\text { Increases with an increase in } \\
\text { temperature }\end{array}$ & $v_{1}\left(\mathrm{PO}_{4}{ }^{3-}\right)$ band sharpening & $(123,147)$ \\
\hline $\mathrm{C} / \mathrm{P}$ & $\begin{array}{l}\text { Decreases with an increase in } \\
\text { temperature }\end{array}$ & $\begin{array}{l}\text { Partial peak overlapping } \\
\text { between } v_{1}\left(\mathrm{CO}_{3}^{2-}\right) \text { and } \\
v_{3}\left(\mathrm{PO}_{4}^{3-}\right)\end{array}$ & $(121)$ \\
\hline \multicolumn{4}{|c|}{ INS spectroscopy } \\
\hline \multicolumn{3}{|c|}{ Spectral alterations } & Reference \\
\hline \multicolumn{3}{|c|}{$\begin{array}{l}\mathrm{OH}^{-} \text {libration band, at } 650 \mathrm{~cm}^{-1} \text {, narrowing with an increase in temperature; } \\
\text { indirectly related to an increase in crystallinity }\end{array}$} & \multirow{2}{*}{$(44)$} \\
\hline \multicolumn{3}{|c|}{$\begin{array}{l}\mathrm{OH}^{-} \text {libration band shift to higher wavenumber values and } \mathrm{OH}^{-} \text {stretching band } \\
\text { shift to lower wavenumber values with an increase in temperature }\end{array}$} & \\
\hline \multicolumn{3}{|c|}{$\begin{array}{l}\text { Peak broadening for samples heated at low temperatures are related to carbonate } \\
\text { substitution. }\end{array}$} & (87) \\
\hline \multicolumn{4}{|c|}{$\mathrm{X}$-ray diffraction } \\
\hline \multirow{2}{*}{\multicolumn{2}{|c|}{ Parameter alterations }} & Diffractogram alterations & Reference \\
\hline & & $\begin{array}{l}\text { At temperatures under } \\
600^{\circ} \mathrm{C} \text {, diffraction peaks are } \\
\text { broadened and overlapped }\end{array}$ & $(54)$ \\
\hline
\end{tabular}




\begin{tabular}{|c|c|c|c|}
\hline & & $\begin{array}{l}\mathrm{CaO} \text { rise at } 775{ }^{\circ} \mathrm{C} \text {, } \\
\text { increasing up to } 1000{ }^{\circ} \mathrm{C}\end{array}$ & (55) \\
\hline & & $\begin{array}{l}\beta \text {-TCP appearance, at } \\
\text { temperatures above }\end{array}$ & $(57)$ \\
\hline & & $1000^{\circ} \mathrm{C}$, is sporadic & \\
\hline \multirow{2}{*}{$\mathrm{CI}$} & $\begin{array}{l}600 \text { to } 800{ }^{\circ} \mathrm{C}-\text { most significant } \\
\text { alterations in crystallinity }\end{array}$ & $\begin{array}{l}\text { Peak narrowing with an } \\
\text { increase in temperature; } \\
\text { little overlapping }\end{array}$ & \multirow{2}{*}{$(54)$} \\
\hline & $\begin{array}{l}\text { Above } 800{ }^{\circ} \mathrm{C} \text { - crystal size, lattice } \\
\text { parameters and microstrain attain a } \\
\text { constant value }\end{array}$ & & \\
\hline $\mathrm{L}$ & $\begin{array}{l}\text { Increases with an increase in } \\
\text { temperature }\end{array}$ & $\begin{array}{l}(002) \text { and (310) peaks get } \\
\text { narrower with an increase } \\
\text { in temperature }\end{array}$ & $(24,135)$ \\
\hline \multicolumn{4}{|c|}{ Neutron diffraction } \\
\hline & Parameter alterations & Spectral alterations & Reference \\
\hline \multirow[t]{2}{*}{$\mathrm{CI}$} & No significant changes upon heating & $\begin{array}{l}\text { (111) peak intensity does } \\
\text { not change upon } 3 \text { days } \\
\text { heating at } 625^{\circ} \mathrm{C}\end{array}$ & $(152)$ \\
\hline & $\begin{array}{l}a \text {-axis and } c \text {-axis expansion with an } \\
\text { increase in temperature }\end{array}$ & $\begin{array}{l}(002) \text { and }(300) \text { peaks get } \\
\text { narrower with an increase } \\
\text { in temperature }\end{array}$ & $(113,128)$ \\
\hline
\end{tabular}




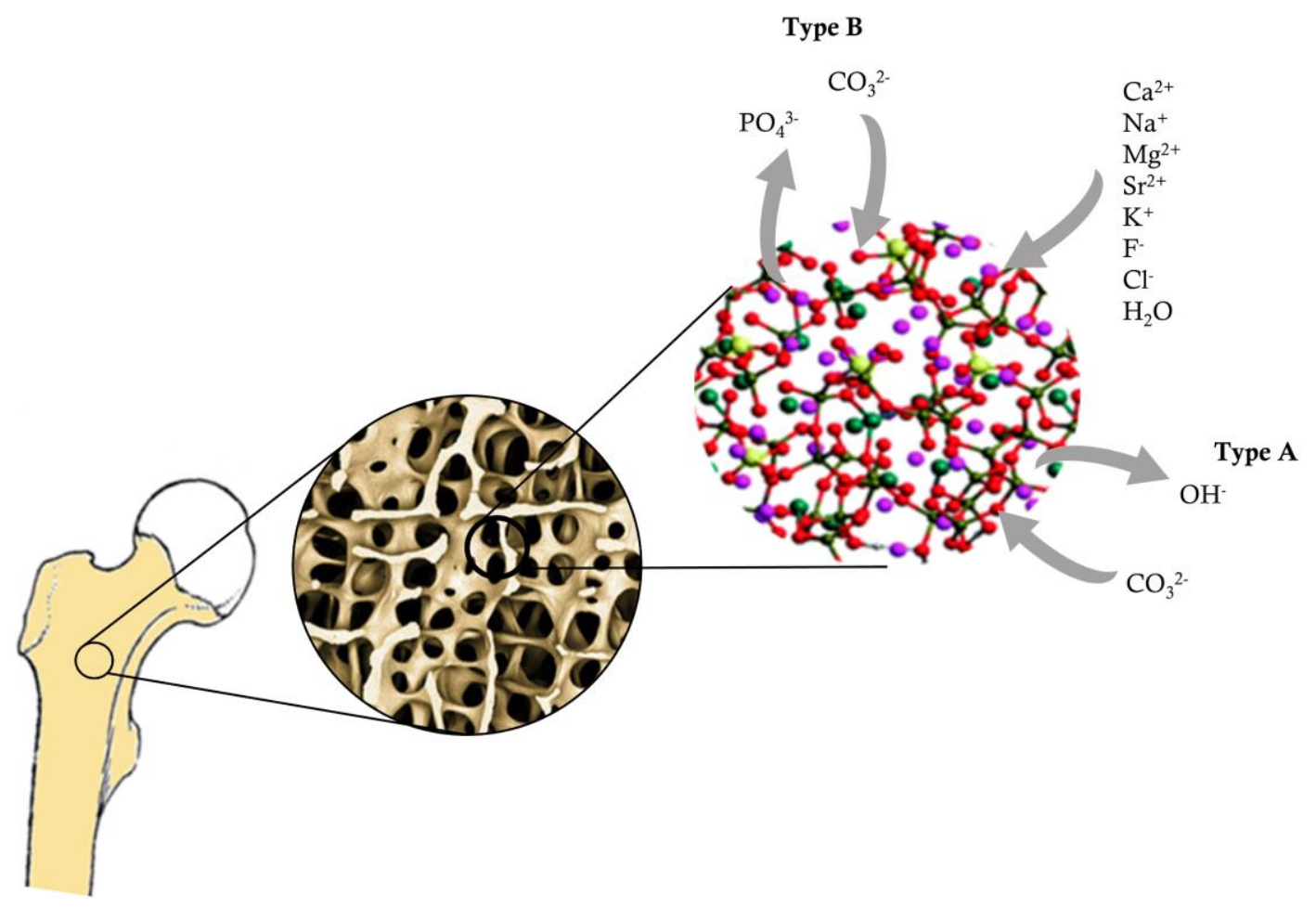

Figure 1.

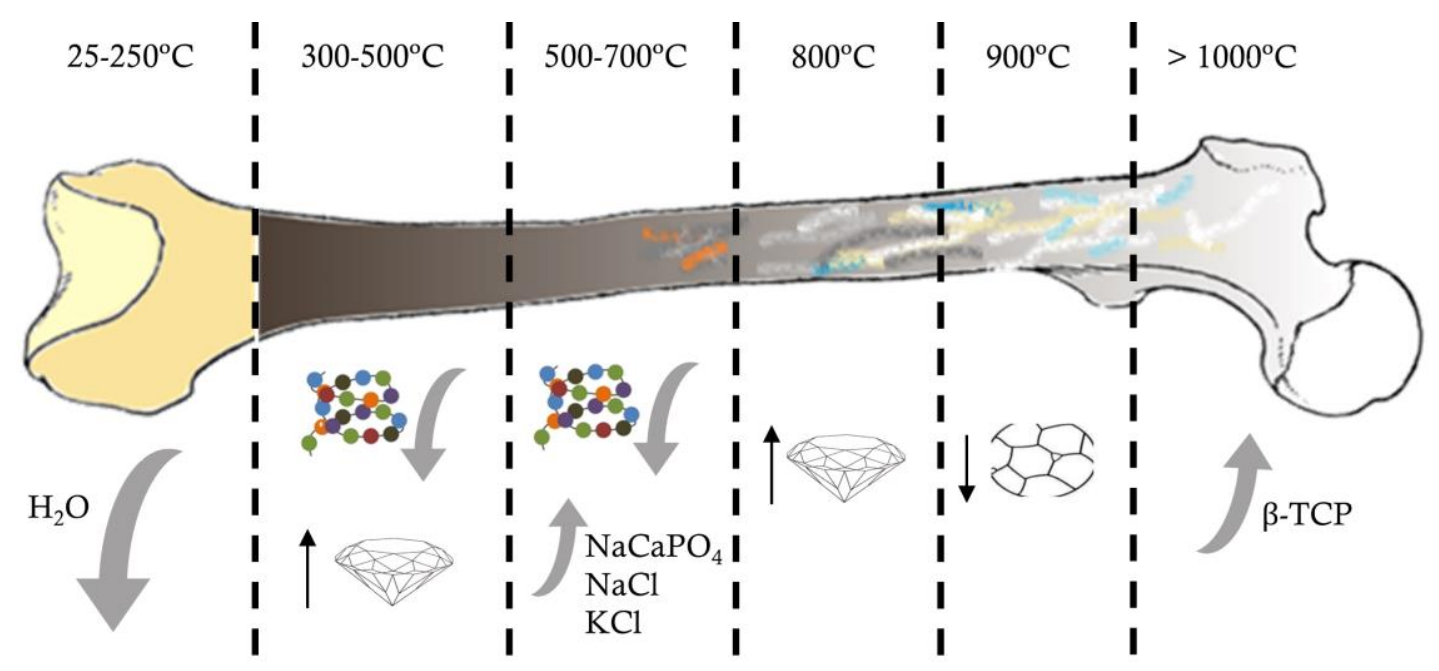

Figure 2. 


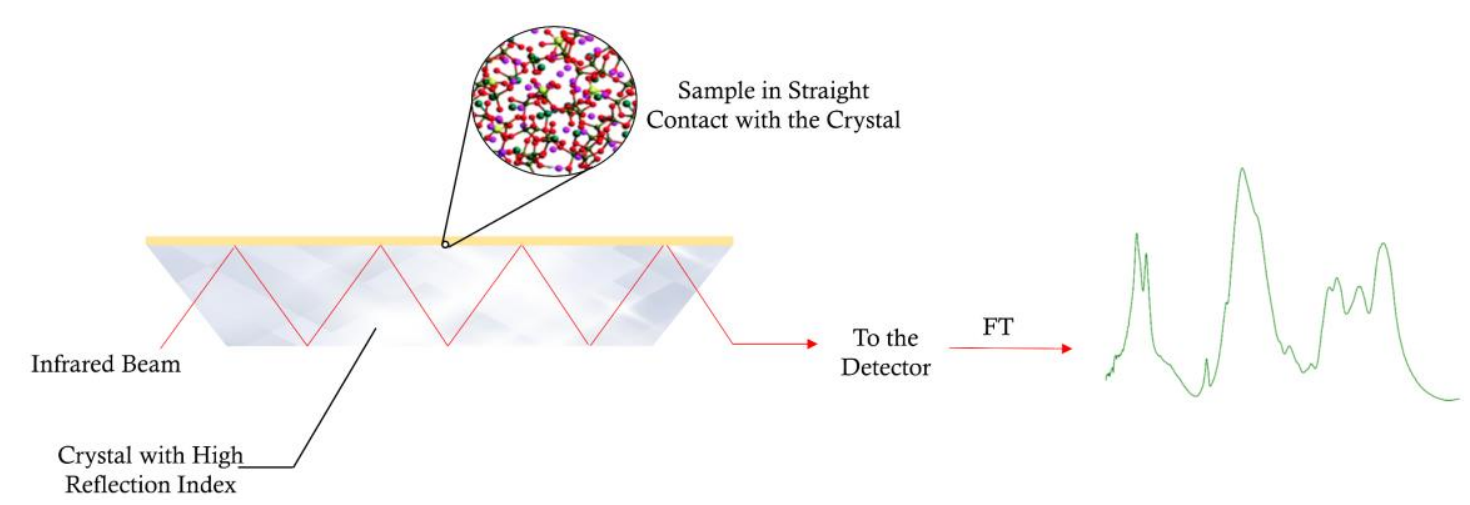

Figure 3.

$\mathrm{E}_{1}$

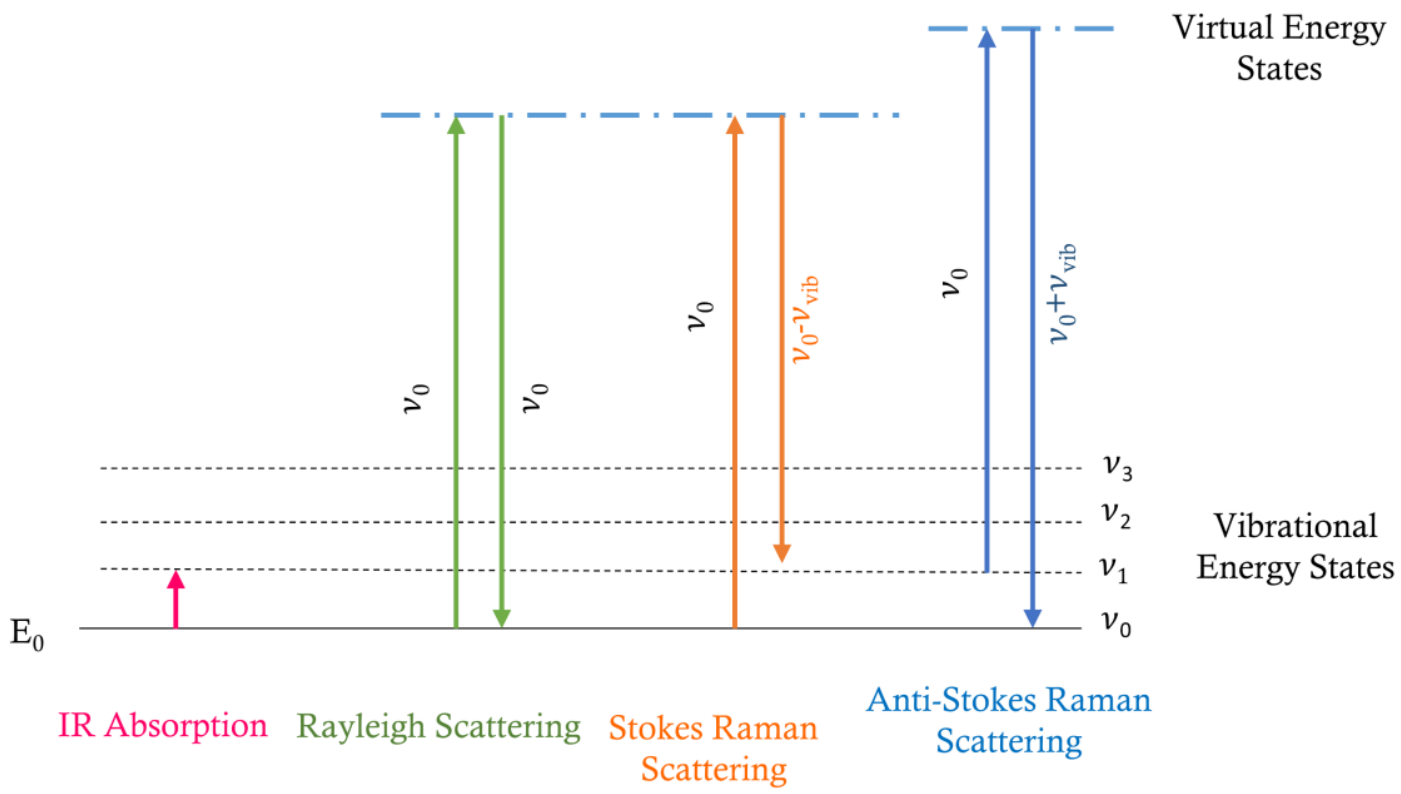

Figure 4. 


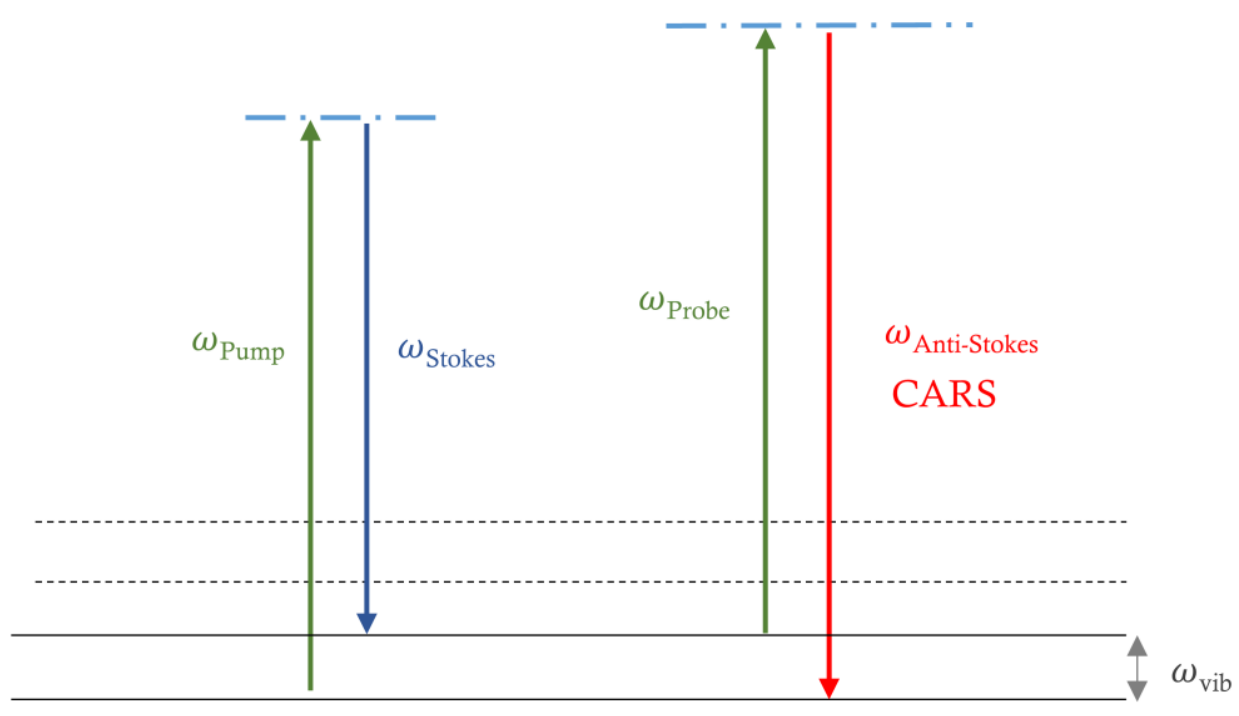

Figure 5.

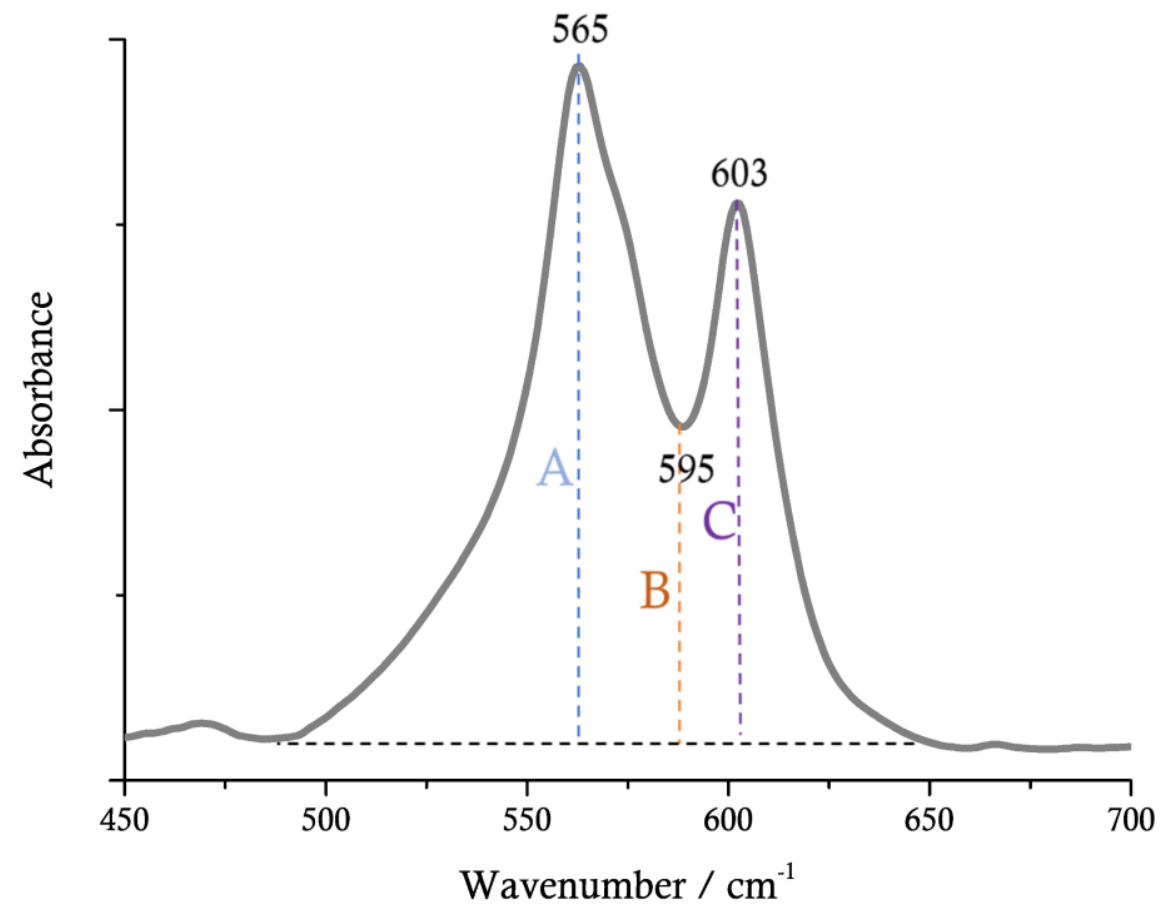

Figure 6. 


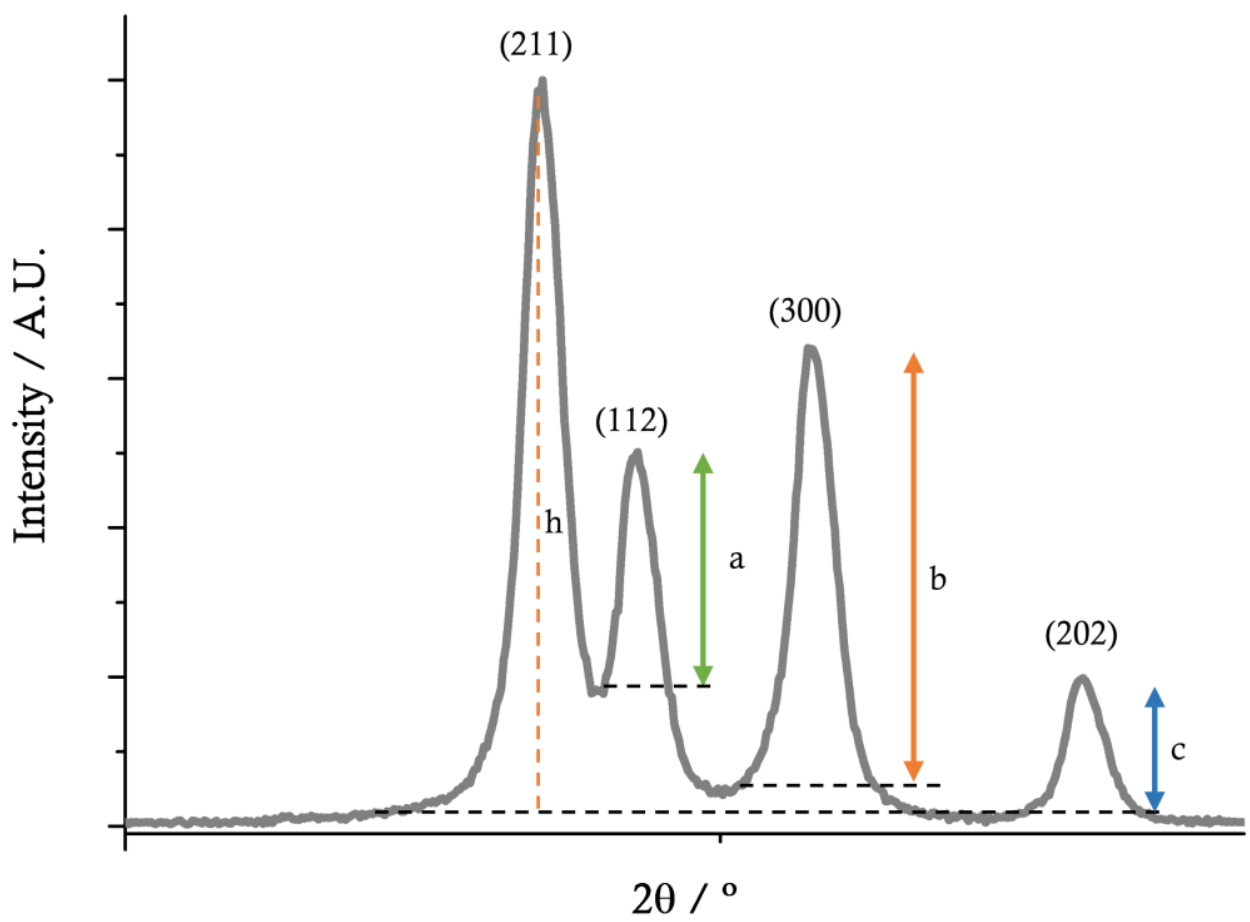

Figure 7. 